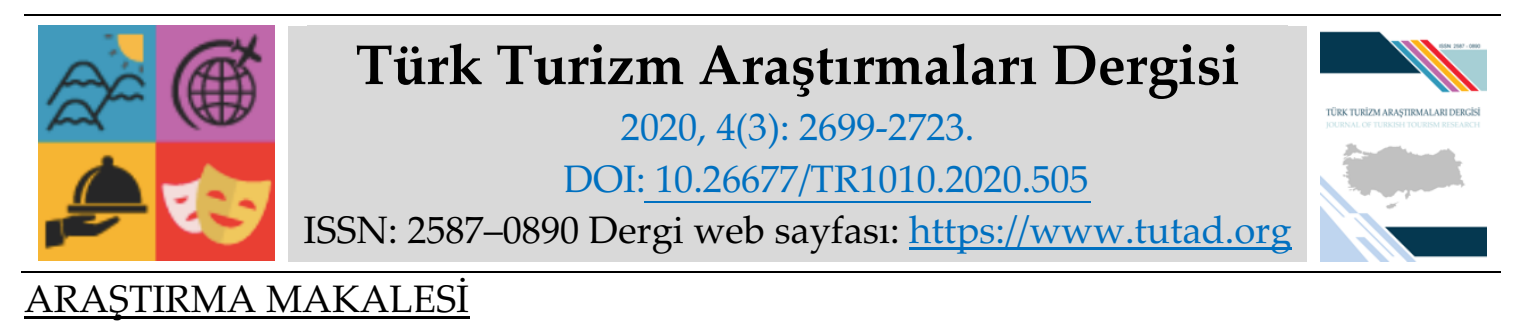

\title{
İşgörenlerin Örgütsel Dışlanma Algılarının Örgütsel Sessizlik ve Olumsuz Durumları Bildirme Eğilimlerine Etkisi: Otel İşletmeleri Örneği
}

Dr. Öğr. Üyesi Nihan YARMACI, İstanbul Gedik Üniversitesi, Güzel Sanatlar ve Mimarlık Fakültesi, İstanbul, e-posta: nihan.yarmaci@gmail.com

ORCID: https://orcid.org/0000-0002-2679-5468

Dr. Öğr. Üyesi Tuğrul AYYILDIZ, Adnan Menderes Üniversitesi, Turizm Fakültesi, Aydın, eposta: tayyildiz@adu.edu.tr ORCID: https://orcid.org/0000-0001-6332-975X

Öz

Sosyal bir varlık olması nedeniyle birey, aidiyet ihtiyacı duymaktadır. Bu durum, bireyin tüm hayatı boyunca farklı topluluk ve gruplara dahil olma ve kedini o topluluk ya da gruplara kabul ettirme çabası sergilemesine neden olur. Dolayısıyla bireylerin çalışma hayatında ya da çalıştıkları işletmedeki sosyal ilişkileri, işletmenin içinde oluşan grup ve alt gruplar tarafından kabul edilmesi bireylerin hem özel hayatına hem de çalışma hayatındaki ilişkilerine yansıyacaktır. Bu durum örgüt açısından; gruplar arası etkileşim ve iletişim, işgörenlerin bireysel performansları üzerinde etkili olabileceği gibi örgüt performansını da etkileyecektir. Özellikle örgütte dışlanan işgörenler, üst yönetim ya da çalışma arkadaşları tarafından dikkate alınmama ve sürekli şikayet eden kişi konumunda olma kaygısından dolayı örgütsel kararlara katılma ve fikir paylaşımı gibi konularda sessiz kalmayı tercih etmekle birlikte, örgüt içerisindeki olumsuz durumlar ile ilgili konuları bildirmemeyi tercih etmektedir. Bu bağlamda araştırmada, turizm sektörü içinde yer alan otel işletmeleri işgörenlerinin örgütsel dışlanma (ostracism) algılarının, örgütsel sessizlik ve olumsuz durumları bildirme (whistleblowing) davranışları üzerindeki etkisinin belirlenmesi amaçlanmaktadır. Araştırmada, veri toplama yöntemi olarak anket tekniğinden faydalanılmıştır. Araştırma sonucunda, örgütsel dışlanmanın örgütsel sessizliği orta düzeyde $(\mathrm{r}=0,366)$ etkilediği, örgütsel dışlanmanın olumsuz durumları bildirmeyi ise orta düzeyde $(r=-0,569)$ etkilediği belirlenmiştir.

Anahtar Kelimeler: Örgütsel Dışlanma, Örgütsel Sessizlik, Olumsuz Durumları Bildirme, Kuşadası, İstanbul.

Makale Gönderme Tarihi: 28.04.2020

Makale Kabul Tarihi: 01.07.2020

\section{Önerilen Atıf:}

Yarmacı, N ve Ayyıldız, T. (2020). İşgörenlerin Örgütsel Dışlanma Algılarının Örgütsel Sessizlik ve Olumsuz Durumları Bildirme Eğilimlerine Etkisi: Otel İşletmeleri Örneği, Türk Turizm Araştırmaları Dergisi, 4(3): 2699-2723.

(C) 2020 Türk Turizm Araştırmaları Dergisi. 


\title{
Journal of Turkish Tourism Research
2020, 4(3): 2699-2723.
DOI: 10.26677/TR1010.2020.505 \\ RESEARCH PAPER
}

\section{The Impact Employees Perceptions of Organizational Ostracism on Organizational Silence and Whistleblowing: Hotel Establishments Case}

Assistant Prof. Dr. Nihan YARMACI, İstanbul Gedik University, Faculty of Fine Arts and Architecture, İstanbul, e-mail: nihan.yarmaci@gmail.com ORCID: https://orcid.org/0000-0002-2679-5468

Assistant Prof. Dr. Tuğrul AYYILDIZ, Adnan Menderes University, Faculty of Tourism, Aydın, e-mail: tayyildiz@adu.edu.tr

ORCID: https://orcid.org/0000-0001-6332-975X

\begin{abstract}
As a social being, individual has a need for its belonging. This causes the individual to be involved in different communities and groups, and try to make himself/herself accepted among these communities and groups throughout one's life. Therefore, social relations of individuals in their work life or at the companies where they work for being accepted by the groups and sub-groups in the company, not only reflects on the private life of individual, but also affects intergroup interaction and relations, individual performance of employees and organizational performance. Employees especially prefer staying silent when it is about participating in organizational decisions and exchange of ideas since they are concerned about being ignored by top management and his/her colleagues and being in the position of someone who complains all the time, and avoid informing others about negative situations within the organization. This issue is more important particularly for hotels carrying out business activities in service sector, in which becoming distinguished among others with different ideas and opinions is essential to achieve competitive advantage. According to the research which determines the employees', who have been working in hotels, perception of organizational ostracism and determining the impact of their perception on the organizational silence and whistleblowing levels. For the survey researcher applied questionnaire technique as a method of data collection. According to the results of basic linear regression organizational ostracism effects organizational silence at the medium level $(\mathrm{r}=0,366)$ and also organizational ostracism effects whistleblowing at the medium level $(\mathrm{r}=0,569)$.
\end{abstract}

Keywords: Organizational Ostracism, Organizational Silence, Whistleblowing, Kuşadası, İstanbul Received: 28.04 .2020

Accepted: 01.07.2020

\section{Suggested Citation:}

Yarmac1, N and Ayyıldız, T. (2020). The Impact Employees Perceptions of Organizational Ostracism on Organizational Silence and Whistleblowing: Hotel Establishments Case, Journal of Turkish Tourism Research, 4(3): 2699-2723.

(c) 2020 Türk Turizm Araştırmaları Dergisi. 


\section{Gíriş}

Bireylerin; gruplar, grup üyeleri ya da bireyler tarafından gördükleri olumlu veya olumsuz davranışlar, iletişim ve insan ilişkilerini etkilemektedir. Kişilerin kendileri ve diğer insanlarla ilgili algılarının yanı sıra kişiler arası ilişkilerinin niteliğini de etkilemektedir. Bu nedenle diğer insanlar tarafından reddedilme ya da grup dışında tutulma şeklinde görülen olumsuz bir tepki insanlarda huzursuzluk, gerginlik, hayal kırıklı̆̆ 1 ve öfke gibi olumsuz duygular yaratmaktadır. Bu durum uzun vadede de çaresizlik, değersizlik, yabancılaşma duyguları, sosyal tecritle birlikte depresyon, hatta intihar fikirleriyle sonuçlanabilmektedir (Blackhart vd., 2009; Ford ve Collins, 2010). Örgüt içerisinde bireyin hiçbir neden belirtilmeksizin diğerleri tarafından dikkate alınmaması ya da bireyden uzak durulması anlamına gelen dişlanma (ostracism) ise işgören bağlllığını etkileyen temel faktörler arasında sayılmaktadır (Leung vd., 2011). İşgörenlerin dışlanmışlık algısı, işletmelerde performans (Seibert vd., 2001; Ferris vd., 2008; Hitlan ve Noel, 2009; Lustenberger ve Jagacinski, 2010; Wu vd. 2011; Leung vd. 2011; Zhao vd., 2013; Yan vd., 2014; Haq, 2014), bağlılık (O’Reilly ve Robinson, 2009; Leung vd., 2011), iletişim, katılımc1 yönetim ve bilgi paylaşımı gibi konuları negatif yönde etkilemektedir. Diğer taraftan dişlanmışlık algısı, işten ayrılma niyeti (Renn vd., 2013; Haq, 2014), yabancılaşma, yalnızlık (Leary vd., 2001), tükenmişlik (Wu vd., 2012), stres (Haq, 2014), sessizlik, çatı̧̧ma ve sinizm gibi olumsuz durumların örgüt içerisinde yaygınlaşmasıyla doğrudan ilişkili olduğu belirtilebilir. Dışlanmışlık algısı ve sessizlik davranışlarına yönelik geliştirilecek politika ve uygulamalar işgörenlerin örgüt içerisinde aktif hale gelmesine katkı sağlayacak ve birçok değişkenden etkilenen olumsuz durumları bildirme eğilimini pozitif yönde etkileyecektir. Bu doğrultuda, otel işletmeleri işgörenlerinin mevcut algılarının belirlenmesi ve bu algının örgütte olumsuz bir etkiye sahip olan örgütsel sessizlik ve örgütün farklılaşmasını sağlayan olumsuz durumların bildirilmesi arasındaki ilişki önemli bir unsur olarak görülmektedir. Ayrıca, literatürde örgütsel dışlanma kavramı ile ilgili çalışmaların sınırlı olması literatüre katkısı açısından bu araştırmanın önemini göstermektedir.

\section{KAVRAMSAL ÇERÇEVE}

Ferris vd. (2008), örgütsel dışlanmayı (ostracism), bir grup içerisinde diğerleri tarafından dikkate alınmama ya da gruba dahil edilmeme şeklinde tanımlamaktadırlar. Bireyler tüm yaşamları boyunca farklı zaman, yer, kişi veya gruplar tarafından dışlanmaya maruz kalabilirler. Bireylerin hayatında önemli bir yere sahip olan çalışma ortamları da bunlardan birisidir. Bu bağlamda değişen yönetim anlayışı işgörenlerin farklı bakış açıları ile örgüte olan katkısı ve pozitif yönlü etkisi arttırılmaya çalışılmaktadır. Çağdaş yönetim tekniklerini benimseyen örgütlerin işgörenlerin olumlu davranışlarını geliştirmeye yönelik uygulamalarının yanı sıra olumsuz durum ve davranışları belirleyerek, çözümler yaratması da büyük önem taşımaktadır. Olumsuz bir durumun belirlenerek, çözümlenmemesi kısa vadede büyük etkilere neden olmasa bile, uzun vadede çözümü olmayan yani örgütün yok olmasında önemli bir faktörü oluşturacaktır. Dolayısıyla bu olumsuz durum ve davranışlardan biri olan örgütsel dışlanmanın, incelenmesi gerekliliğini ortaya çıkartmaktadır. Örgütlerde dışlanan bireylerde iş tatminsizliği, örgüte bağlılığın azalması ve işten ayrılma niyetinin artması gibi sonuçlar ortaya çıkartmaktadır (O’Reilly ve Robinson, 2009; Haq, 2014). Ayrıca, örgütsel dişlanma işgörenlerin performansı üzerinde de olumsuz etkiler oluşturmaktadır. Örneğin, bireyin dışlanmaya maruz kalması, zamanını ve enerjisini kişilerarası ilişkilerini düzeltmek için harcaması ve bu durumun görev ve sorumluluklarını yerine getirememesi, aksatması hatta performansının düşmesine (Ferris vd., 2008; Leung vd., 2011) neden olmaktadır. Dolayısıyla dışlanma, örgütteki diğer işgörenler ile 
sosyal bağları zayıflayan ya da yok olan işgörenin işi ile ilgili önemli bilgi ve kaynaklara ulaşamamasında ve performansının düşmesinde önemli bir etkiye sahiptir (Wu vd., 2011).

Örgütsel dışlanma, işgörenlerin bilgi saklama ve ses yani fikir ve düşüncelerini ifade etme gibi potansiyel davranışlarını da olumsuz yönde etkileyerek, engellemektedir (Jones vd., 2009; Gkorezis vd., 2016; Zhao ve Xia, 2017; Fatima vd., 2017). Bu durum, örgüt içerisindeki problemler ile ilgili işgörenlerin fikir ve düşüncelerini kendilerine saklaması ya da paylaşmaması olarak tanımlanan örgütsel sessizliğin görülmesine neden olmaktadır. Ayrıca, örgütsel sessizlik örgütün değişim ve gelişimine engel olan önemli faktörler arasında kabul edilmektedir (Morrison ve Milliken, 2000:707-721). Örgüt açısından önemli bir kaynak olan işgörenlerin düşünce ve fikirlerini açıkça paylaşmaması, önemsenmeme, fark yaratmayacağı algısı ya da diğer işgörenler tarafından negatif bir insan olarak görülme (Milliken vd., 2003:1454) yani dışlanma kaygısından kaynaklanabilmektedir. Farklı bir bakış açısına göre, işgörenin olumsuz tutum sergilemesi, duymaması, bilerek ve isteyerek kendini örgütten dışlaması ve yazmaması örgütsel sessizlik olarak (Bayın vd., 2015:250) değerlendirilmekte olup, örgütsel dişlanma ile örgütsel sessizlik kavramları hem birbirlerinin öncülü hem de sonucu olarak değerlendirilebilir. Kariyerlerini tehlikeye atmak istemeyen işgörenler susmayı tercih etmektedirler. Kendilerini koruyacak ya da koruma altına alacak herhangi bir örgüt politikası, düzeni veya yasal düzenleme olmadığından dolayı olumsuz durumları bildiren işgören (whistleblower) olmak istememektedirler (Miceli ve Near, 1984:687-704; Çiğdem, 2013:106). Bununla birlikte, bildirme eylemi sonucunda diğer işgörenler tarafından işgörenin kötü ve soğuk davranışlara maruz bırakılması, dışlanması, işten çıkarılması, ayırımcı davranışlara maruz kalması, küçük düşürülmesi ve bu işgöreni korumak için gerekli politika ve uygulamaların eksikliği bu davranışın tercih edilmemesinde etkili olan nedenler olarak vurgulanmaktadır (Callahan ve Collins, 1992:939). Ayrıca, olumsuz durumları bildirme davranışı yalnızca dışsal bildirme olarak gerçekleşmemektedir. Aynı zamanda içsel bildirme şeklinde de görülebilen bu davranış işgörenin farkına vardığı durum ya da problem hakkında bilgi, fikir ve endişeleri paylaşması açısından değerlendirildiğinde örgütsel sessizliğin zıttı olan örgütsel ses davranışı ile benzerlik göstermektedir. Dolayısıyla, sağlıklı bir iş ortamının oluşturulması ve geliştirilmesinde etkili olan bu unsurların doğru politika ve stratejilerle yönetilmesi gerekliliği önem kazanmaktadır. Turizm ve otel işletmeleri açısından işgörenlerin katkısının diğer işletme türlerine göre daha fazla olması bu konuların göz ardı edilmemesini gerekli hale getirmektedir. Özellikle hizmet sektörü içerisinde yer alan otel işletmeleri açısından ele alındığında, hizmetin özelliklerinden dolayı sunumu sırasında gözlenebilen yasal, etik veya hatalı uygulamalar ile ilgili geri bildirim sağlanabilmesinde işgörenin önemi ön plana çıkmaktadır. Ayrıca bildirim sağlayan işgörenlerin kendileri hakkında sorunlu veya problemli olarak düşünülmeyeceğini bilmesi ve işletmedeki diğer bireyler tarafından görmezden gelme, dikkate alınmama gibi durumların ortaya çıkmaması bildirimlerin üzerinde pozitif bir etki yaratması açısından konunun önemini vurgulamaktadır. Başka bir bakış açısıyla ise otel işletmelerinin emeğe olan bağlılık düzeylerinin yüksek olması, işgörenlerden en yüksek düzeyde verim alınabilmesi için örgüt kültürü ve çalışma ortamındaki ilişkilerin etkisini arttırmaktadır. Bu bağlamda söz konusu örgütsel dişlanma işletme ve işgörenler üzerinde olumsuz etkiler yaratmaktadır. Bu etkiler olumsuz örgütsel davranışı tetiklemekte ve genellikle örgütsel sessizlik ve olumsuz durumları bildirmeme davranışlarının gözlenmesine neden olmaktadır.

Özellikle hizmet kalite algısının hizmetin sunulduğu anda oluşması turizm işletmeleri gibi emek yoğun özellik gösteren işletmelerde verimlilik, imaj, itibar ve rekabet üstünlüğü açısından insan faktörünün etkisini göstermektedir. Bu unsurun olumsuz yönde etkilenmesi hem işletme hem de takım çalışmasının daha fazla görüldüğü işletmelerdeki işgörenleri de etkilemektedir. Bireylerin yalnızlaşmaktan kaçınmaları ve kabul görme ihtiyacı duymalarının yanı sıra izolasyon ya da dışlanma korkusu, aynı fikirde olmasa bile çoğunluğa katılmaları (Çakıcı, 2007:153) veya 
düşüncelerini söylemek yerine susmayı tercih etmelerine neden olmaktadır. Örgütlerde olumsuz etkilere sebep olan unsurlardan biri de örgütsel dışlanma olup, örgütte çalışmaya yeni başlayan veya uygulama/durumlarla ilgili farklı düşüncelerini dile getiren işgörenlerin üst yönetici ya da çalışma arkadaşları tarafından dışlandığı görülmektedir. Çalışma arkadaşları veya üst yönetim tarafından problemli bireyler olarak algılanmak istemeyen işgörenler, bazı durumlarda hatalı veya yanlış uygulamaları ve alınan kararları bildirmek yerine sessizliği tercih etmektedirler. (Çiğdem, 2013:106). İşgörenlerin izolasyon korkusu, fikirlerini ifade ettiklerinde baş belası, dedikoducu veya şikayetçi olarak tanımlanmak istememeleri, ayrıca iş arkadaşları ile olan ilişkilerinin bozulmasını istememeleri sebebiyle de sessizlik eğilimi gösterebilmektedirler. (Bildik, 2009; Sayğan, 2011). Örgüt içerisinde işgörenlerin sessizleşmesinde etkili olan değişkenlerden biri de örgütsel dışlanmadır. Bu doğrultuda araştırmanın birinci hipotezi şu şekilde oluşturulmuştur;

Hipotez 1: Otel işletmeleri işgörenlerinin örgütsel dışlanma (ostracism) algılarının örgütsel sessizlik düzeyleri üzerinde anlamlı bir etkisi vardır.

Yukarıda verilen 1. araştırma hipotezi kapsamında test edilecek olan araştırmada dişlanmanın örgütsel sessizliğin alt boyutları üzerindeki etkisi de alt hipotezler aracıllğ̆ıyla istatistiksel olarak test edilmek üzere oluşturulmuştur;

Hipotez1a: Otel işletmeleri işgörenlerinin örgütsel dışlanma algılarının kabullenici sessizlik düzeyleri üzerinde anlamlı bir etkisi vardır.

Hipotez1b: Otel işletmeleri işgörenlerinin örgütsel dışlanma algılarının savunmacı sessizlik düzeyleri üzerinde anlamlı bir etkisi vardır.

Hipotez1c: Otel işletmeleri işgörenlerinin örgütsel dışlanma algılarının örgüt yararına sessizlik düzeyleri üzerinde anlamlı bir etkisi vardır."

Olumsuz durumlarının bildirilmesi, işgörenler tarafından olumlu bir davranış olarak kabul edilmemektedir. Bildirimi gerçekleştiren işgörenlere karşı ispiyoncu, sıçan, köstebek, gammaz, hain (Bayrakçı ve Kayalar, 2016:121) gibi aşağılayıcı sıfatlar kullanılmakta ve bu işgörenler dışlanmaktadır (Ateş vd., 2009:48). Ayrıca işgörenlerin bildirme eylemi sonunda diğer çalışma arkadaşları tarafından kötü ve soğuk davranışlara maruz bırakılarak dışlanması, görevden alınması veya işten atılması (Barry, 2007), ayırımcı davranışlara maruz kalması ve herkes içinde küçük düşürülerek, korunması için gerekli politika ve uygulamaların olmayışı nitelikli nedenler olarak vurgulanmaktadır (Callahan ve Collins, 1992:939). Bu doğrultuda, örgütlerde negatif durumların oluşmasında etkili olan örgütsel dışlanma ve örgütsel sessizlik kavramlarının ortadan kaldırılması ile örgütsel ve bireysel düzeydeki olumsuz etkilerinin azalması sağlanabilecek ve örgütün farklılaşmasını sağlayan olumsuz durumların bildirimi gibi pozitif etkiye sahip davranış ve durumların gelişmesine katkı sağlanacaktır. Bu doğrultuda araştırmanın ikinci hipotezi şu şekilde oluşturulmuştur;

Hipotez 2: Otel işletmeleri işgörenlerinin örgütsel dışlanma (ostracism) algılarının olumsuz durumları bildirme (whistleblowing) biçimleri üzerinde anlaml bir etkisi vardır.

İkinci hipotez kapsamında araştırmada dışlanmanın olumsuz durumları bildirme şekilleri üzerindeki etkisi de alt hipotezler aracıllğıyla istatistiksel olarak test edilmek üzere şu şekilde oluşturulmuştur;

Hipotez2a: Otel işletmeleri işgörenlerinin örgütsel dışlanma algılarının içsel bildirme eğilimi üzerinde anlaml bir etkisi vardir.

Hipotez2b: Otel işletmeleri işgörenlerinin örgütsel dışlanma algılarının dışsal bildirme eğilimi üzerinde anlaml bir etkisi vardir. 
Hipotez2c: Otel işletmeleri işgörenlerinin örgütsel dışlanma algılarının kimlikli bildirme eğilimi üzerinde anlaml bir etkisi vardir.

Hipotez2d: Otel işletmeleri işgörenlerinin örgütsel dışlanma algılarının gizli bildirme eğilimi üzerinde anlaml bir etkisi vardir.

Hipotez2e: Otel işletmeleri işgörenlerinin örgütsel dışlanma algılarının resmi bildirme eğilimi üzerinde anlaml bir etkisi vardir.

Hipotez2f: Otel işletmeleri işgörenlerinin örgütsel dışlanma alğlarının gayri resmi bildirme eğilimi üzerinde anlamlı bir etkisi vardır.

Literatürde örgütsel dışlanmaya yönelik yapılan araştırmalar incelendiğinde, işletmeler açısından olumsuz sonuçlar ortaya çıkardığına yönelik bulgular belirlenmiştir. Örgütsel dışlanma ile ilişkili değişkenler incelendiğinde, örgütsel bağlllık (O'Reilly ve Robinson, 2009; Leung vd. 2011), vatandaşlık (Liu ve Wang, 2011), performans (Seibert vd., 2001; Ferris vd., 2008; Hitlan ve Noel, 2009; Lustenberger ve Jagacinski, 2010; Wu vd., 2011; Leung vd., 2011; Zhao vd., 2013; Yan vd., 2014; Haq, 2014), içsel motivasyon (Lusterberger ve Jagacinski, 2010), iletişim, katılımcı yönetim ve bilgi paylaşımı açısından olumsuz etkilerin olduğu vurgulanmaktadır. Örgütsel dışlanmanın işten ayrılma niyeti (Renn vd. 2013; Haq, 2014), yabancılaşma, yalnızlık (Leary vd., 2001) tükenmişlik (Wu vd., 2012), stres (Haq, 2014), çatışma ve sinizm gibi değişkenlerle doğrudan pozitif yönde ilişkili olduğu belirtilmektedir. Ayrıca Hitlan vd. tarafından 2006 yılında yapılan araştırma sonucu örgütsel dışlanmanın cinsiyet, yaş, eğitim, statü ve etnik köken gibi demografik değişkenlerinde ilgili olduğu, Miceli vd., (2001) yaptıkları çalışmada ise olumsuz durumları bildirme davranışının da bireysel farklılık ve özelliklerle ilişkili olduğu sonucuna ulaşmıştır.

\section{YÖNTEM}

$\mathrm{Bu}$ araştırmanın amacı, işgörenlerin örgütsel dışlanma (ostracism) algılarının örgütsel sessizlik ve olumsuz durumları bildirme (whistleblowing) eğilimleri üzerindeki etkisini tespit etmektir. Bu sayede, yöneticiler ile işgörenler arasında etkili geri bildirim, sağlıklı iletişim ve uygulamalar ile ilgili faydalı önerilerin paylaşılması hedeflenmektedir. İnsan kaynakları departmanı açısından ise örgüte olan bağlılık, özdeşleşme ve iş gücü devir oranını düşürmenin yanı sıra işgörenlerin iş tatmin düzeylerinin pozitif yönde etkileyebilecek strateji ve politika oluşturmada da önemli katkılar sağlanması amaçlanmaktadır. Bu doğrultuda araştırma, otel işletmelerinde uygulanmakta olan insan kaynakları politikalarının yeniden şekillendirilmesinde bilimsel verilerden yararlanılmasına olanak sağlanacaktır. Ayrıca, araştırma konusuna ilişkin sınırlı çalışmanın bulunması nedeniyle literatüre yeni bir kaynak kazandırılması hedeflenmektedir.

Küresel rekabet ortamında işletmelerin en önemli farklılık unsurlarından biri olarak işgörenler kabul edilmekte olup, değişen yönetim yaklaşımları ile örgütler yenilikçi, farklı düşünce ve fikirlere açık yani işgörenlere olan bakış açısını değiştirdiği şeklinde ifade edilebilir. Örgütlerin rekabet üstünlüğü sağlayabilmesi için katılımcı yönetim anlayışı, etkili iletişim, güçlendirme, geri bildirim ve farklılıklara açık olması ile doğrudan ilişkilidir. Literatürde olumlu örgütsel davranış konularını geliştirme ve desteklemeye yönelik çalışmalar bulunmasına rağmen, eğer işgörenler sessizleşmiş, dışlanmış ve dikkate alınmayacağını düşündüğü için olumsuz bir uygulamayı üst yönetim ile paylaşmıyor ise bu durum örgütün performansını (Morrison ve Milliken, 2000; Premeaux, 2001; Erdoğan, 2011; Wu vd., 2011), etkili iletişim düzeyini (Gül ve Özcan, 2011; Şimşek, 2011; Kahya, 2013; Aktaş ve Şimşek, 2015), işgörenlerin örgütsel bağlllık düzeyini (Milliken ve Morrison, 2003; Çakıc1, 2007; Ferris vd., 2008; Çakıc1, 2008; Özgen ve Sürgevil, 2009; Taşkıran, 2010) ve kendilerine olan güvenlerinin (Çakıcı, 2007; Ferris vd., 2008; Taşkıran, 2010) 
azalmasına neden olacaktır. Ayrıca bazı çalışmalarda ise işgörenlerin bağlılığının örgütsel sessizliğe (Eroğlu vd., 2011) neden olduğuna yönelik sonuçlara ulaşılmıştır. Bu doğrultuda, otel işletmelerinde örgütsel dışlanma düzeyini belirlemek ve bu algı düzeyinin örgütsel sessizlik ve olumsuz durumların bildirilmesi üzerindeki sonuçlarını incelenmesi önem taşımaktadır. Dışlanma davranışının örgüt açısından değerlendirilmesi ile çalışma ortamında bu duruma yönelik etkin çözüm önerileri geliştirilmesini sağlayacaktır.

Araştırmanın evrenini İstanbul ve Aydın'ın Kuşadası ilçesinde faaliyet gösteren beş yıldızlı otel işletmeleri işgörenleri oluşturmaktadır. Araştırmanın evreni olarak İstanbul ve Kuşadası'nın belirlenmesindeki temel neden, şehir otelleri bakımından İstanbul'un Türkiye turizminde önemli bir paya sahip olması, Aydın'ın Kuşadası ilçesinin deniz-kum-güneş turizminde turistlerin tercih ettiği önemli bir destinasyon olmasıdır. Kültür ve Turizm Bakanlığı (2015) verilerine göre İstanbul'da 84 tane ve Aydın'ın Kuşadası ilçesindeki 15 tane (İlçe Kültür ve Turizm Müdürlüğü, 2016) beş yıldızlı otel bulunmaktadır. Evreni oluşturan birimlerin çok fazla sayıda olması, zaman, maliyet ve uzaklık gibi kısıtlardan dolayı (Karasar, 2008:11) örneklem alınma yoluna gidilmiştir. Olasılıklı örnekleme yöntemlerinden; tabakalı ve küme örnekleme yöntemlerinden yararlanılmıştır. Tabakalı örnekleme ile farklı özellikleri içeren evren kendi içinde homojen alt gruplara ayrılmıs, küme örnekleme yöntemi ise evren birimlerinin arasındaki mesafe uzak olduğu (Ural ve Kılıç, 2010) için kullanılmıştır. Araştırmanın evreni beş yıldızlı sayfiye ve şehir otelleri şeklinde tabakalı örnekleme yöntemiyle iki tabakaya ayrılıp, Aydın'ın Kuşadası ilçesi ve İstanbul ilinde bulunan beş yıldızlı otel işletmeleri de küme olarak örnekleme alınmıştır. Bu doğrultuda, küme örnekleme yöntemi (Ural ve Kılıç, 2010:41) ile her bir ili temsilen beş yıldızlı otel işletmeleri seçilmiştir. Otel işletmelerindeki işgören sayılarına yönelik düzgün istatistikler tutulmaması ve güvenilir bilgiye ulaşılmaması nedeniyle, Türkiye'de beş yıldızlı bir otel işletmesinde oda başına düşen personel sayısı 1.18 ve yatak başına düşen personel sayısı ise 0,59 (Ağaoğlu, 1992; Pelit, 2008) olarak belirtilen "Otelcilik ve Turizm Sektöründe İsggücü Araştırması" ndaki (1989) veriler kullanılarak, otel işletmelerinde güvenilir olarak ulaşılabilen oda ve yatak kapasitelerine yönelik sayılar doğrultusunda evren ve örneklem hesaplamaları yapılmıştır. Turizm işletme belgeli İstanbul'da 84 tane 5 yıldızlı otel işletmesinin toplam yatak kapasitesi 42.578'dir (Kültür ve Turizm Bakanlığı, 2015). Aydın'ın Kuşadası ilçesindeki 15 tane beş yıldızlı otel işletmesi ise toplamda 12.036 yatak kapasitesine (Kültür ve Turizm Bakanlığı, 2017) sahiptir. Beş yıldızlı otel işletmeleri için, yatak başına düşen personel sayısı 0,59 olduğuna göre, İstanbul için toplam 42.578 yatak için personel sayısı (42.578 x 0,59) “25.121”, Kuşadası için toplam yatak kapasitesi 12.036 yatak başına düşen personel sayısı ise $(12.036$ x 0,59) "7.101" olmaktadır. İstanbul ve Kuşadası örnekleme hacmi için toplam evreni oluşturan birim sayısının on binden büyük olması dikkate alınarak, Özdamar (2001:257) tarafından sınırsız evrenler $(\mathrm{N}>10.000)$ ve nicel araştırmalar için önerilen formülünden yararlanılmıştır. Bu formüldeki parametrelerden $\sigma$ standart sapma değeri 85 anket üzerinden yapılan pilot uygulama sonucunda 1,4 olarak hesaplanmıştır. $Z \alpha$ ise 0,05 anlamlılık düzeyine karşılık gelen teorik değer 1,96 olup, $\mathrm{d}$ ise evren ile örneklem ortalaması arasında izin verilebilir maksimum farktır ve etki genişliğini ifade etmektedir. Beşli Likert tipi derecelendirme için ölçek tam puanı olan 5'in \%2'si olan 0,1 olarak belirlenmiştir. Yukarıda verilen formüllere göre, İstanbul ve Kuşadası için minimum örneklem hacmi n=753 olarak hesaplanmaktadır. Araştırmada hedeflenen minimum örneklem hacmine ulaşabilmek için, İstanbul'da 22 tane beş yıldızlı otelin insan kaynakları departmanına 40 'ar adet anket dağıtılmıştır. Elde edilen minimum örneklem hacmine göre, eksik, hatalı ve geri bildirim elde edilemeyecek veriler dikkate alınarak, İstanbul'da toplam 880 anket dağıtılmış ve bunlardan 600 anket geri dönmüş ve 558 anket değerlendirmeye değer görülmüştür. Kuşadası'nda ise 9 tane beş yıldızlı otelin insan kaynakları departmanına 50'şer adet anket elden teslim edilmiştir. Kuşadası'nda toplam 450 anket dağıtılmış ve bunlardan 428 anket geri dönmüş ve 399 anket değerlendirmeye değer görülmüştür. Beş yıldızlı otel işletmelerinde gerçekleştirilen 
anket uygulamasının otellerin konumuna göre dağılımı yer almaktadır. İstanbul (şehir otelleri) $\% 58,30$ 'unu, Kuşadası (sayfiye otelleri) \%.41,70'ini oluşturmaktadır. Örgütsel dışlanma ile ilgili yapılan çalışmalar incelendiğinde, sosyal kaygı, utanma, düşük öz saygı, sinirlenme, depresyon, işten ayrılma niyeti ve işgören yalnızlığı gibi bazı olumsuz etkileri olduğu belirtilmektedir (Baumeister ve Tice, 1990; Chow vd., 2008; Finne vd., 2011:277). Araştırma sırasında örgütsel dışlanma ile ilgili veri toplama tekniği olarak anket tekniğinin kullanılması tercih edilmiştir. Örgütsel dışlanmayı ölçmek için kullanılacak olan ölçek yerli ve yabancı literatür tarafından kabul görmüş ve yaygın olarak kullanılmakta olan Ferris vd. (2008)'in ölçeği kullanılmıştır. Örgütsel dışlanma ile ilgili sınırlı çalışma bulunmakla birlikte, turizm işletmeleri açısından da yerli ve yabancı literatürde birkaç araştırma bulunmaktadır. Araştırmanın değişkenlerinden biri olan işgörenlerin örgütsel sessizlik düzeyleri ile ilgili Van Dyne vd., (2003) tarafından geliştirilen ölçeğin kullanılması kararlaştırılmış olup, yerli ve yabancı literatürde konu ile ilgili yapılan araştırmalar incelendiğinde genellikle araştırma tekniği olarak anket uygulaması gerçekleştirildiği belirlenmiştir (Vakola ve Bouradas, 2005; Huang vd., 2005; Çakıcı ve Çakıcı, 2007; Ehtiyar ve Yanardăg, 2008; Karacaoğlu ve Cingöz, 2009; Bildik, 2009; Ülker ve Kanten, 2009). Araştırma kapsamında ele alınan diğer konu olan işgörenlerin olumsuz durumları bildirme eğilimini belirlemek için anket tekniğinden yararlanılmasına ve Park vd., (2005; 2008) tarafından geliştirilerek literatürde yayın olarak kabul gören ölçeğin kullanılmıştır. Anket uygulaması 01.07.2017-20.12.2017 tarihleri arasında alan araştırması gerçekleştirilmiştir. İşgörenlerin örgütsel dışlanma algısının olumsuz durumları bildirme eğilimi ve örgütsel sessizlik düzeyleri arasında anlamlı bir etkisi basit doğrusal regresyon analizleri ile test edilmiştir. İşgörenlerin örgütsel dışlanma algılarının örgütsel sessizlik ve olumsuz durumları bildirme eğiliminin alt boyutları üzerindeki etkisi ise çoklu doğrusal regresyon testi ile analiz edilmiştir.

\section{BULGULAR ve TARTIŞMA}

Aydın'ın Kuşadası ilçesi ve İstanbul ilinde faaliyet gösteren 5 yıldızlı otel işletmelerindeki işgörenlerin örgütsel dışlanma algılarının örgütsel sessizlik ve olumsuz durumları bildirme eğilimi ile arasındaki ilişkini ve etkilerini belirlemeye yönelik analizlerden elde edilen bulgulara yer verilmektedir. Araştırmada kullanılan ölçeklerin güvenirlik analizi sonuçlarına göre toplam varyansı açılama oranları; örgütsel dışlanma \%62,426' sını, örgütsel sessizlik ölçeğini oluşturan üç boyutun (kabullenici, savunmacı ve örgüt yararına sessizlik) \%67,018'ini ve olumsuz durumları bildirme ölçeğini oluşturan altı boyutun (içsel, dışsal, gayri resmi, resmi, kimlik, gizli) $\% .82,516$ 'sini açıladığı tespit edilmiştir. Ölçeklerin Cronbach's Alpha katsayıları sırasıyla örgütsel dışlanma 0,89, olumsuz durumları bildirme 0,84 ve örgütsel sessizlik ise 0,726 olarak hesaplanmıştır.

Araştırmaya katılan toplam 957 otel çalışanının bazı kişisel bilgilerine ilişkin yüzde ve frekans dağılımları incelendiğinde; katılımcıların \%41,5'i kadın, \%55,i erkek, \%49,3'ü bekar \%46,2'si ise evlidir. Katılımcıların bazı kişisel bilgilerine ilişkin yüzde ve frekans dağılımları incelendiğinde; katılımcıların \%41,5'i kadın, \%55,i erkek, \%49,3'ü bekar \%46,2'si ise evlidir. Araştırmaya katılan çalışanların $\% 10^{\prime} 7^{\prime}$ 'si ilköğretim, \%36,5'i lise, \%24,7'si ön lisans, \%21,3'ü lisans, \%1'i ise lisansüstü eğitim düzeyine sahip olup, katılımcıların yaş gruplarına göre ağırlıklı olarak dağılımları incelendiğinde; \%15,2'si çalışanların 20 veya altı yaş aralığında, \%28,6'sı 21-38 yaş aralığında, \%28,1'i 29-36 yaş aralığında, \%17,3'ü 37-44 yaş aralığında, \%8,2'si 45-52 yaş aralığında ve \%1,6'sı ise 53 yaş ve üstünde çalışanlardan oluşmaktadır. Katılıcıların sektörde çalışma sürelerine göre dağıllım incelendiğinde ise \%15'i 1 yıl ve daha az süre, \%25,3'ü 2-4 yıl, \%22,2'si 5-7 y1l, \%15,6'sı 810 yıl, \%19,9'u 10 yıl ve üzeri süredir turizm sektöründe çalışmaktadır. Araştırmaya katılan çalışanların \%30,3'ü 1 yıl veya daha az süre, \%33,9'u 2-4 yıl, \%16,6'sı 5-7 yıl, \%7,2'si 8-10 yıl, 
\%6,2'si ise 10 yıl ve üzeri süredir aynı işletmede çalışmaktadır. Çalışanların departmanlara göre dağılımına bakıldığında, \%44,4'ü yiyecek-içecek, \%17,8'i kat hizmetleri, \%11,6'sı diğer (spa, muhasebe, güvenlik vb.), \%10,9'u önbüro, $\% 2^{\prime}$ si halkla ilişkiler, $\% 4,5^{\prime}$ i insan kaynakları ve $\%$ 6,4'ü satış pazarlama departmanında çalışanlardan oluşmaktadır. Katılımcıların gelir düzeylerine göre dağılımları incelendiğinde; \%21,7' si 1300 TL veya daha az gelir aralığında, \%33,9'u 1301-1900 TL aralığında, \%23,8'i 1901-2500 TL aralığında, \%9'u 2501-3100 TL aralığında ve \%6,1'i ise $3101 \mathrm{TL}$ veya daha fazla miktarda bir gelir aralığında olduğunu belirtmiştir. Tablo 1'de araştırmaya katılan işgörenlerin örgütsel sessizlik ve alt boyutlarına ilişkin aritmetik ortalama ve standart sapma değerlerine yer verilmiştir.

Tablo 1. Örgütsel Sessizlik Ölçeğinin Boyutlarına İlişkin Betimsel İstatistikler

\begin{tabular}{|l|c|c|}
\hline IFADELER & $\bar{X}$ & SS \\
\hline Kabullenici Sessizlik & 2,33 & 1,04 \\
\hline Savunmacı Sessizlik & 2,09 & 1,08 \\
\hline Örgüt Yararina Sessizlik & 3,68 & 1,10 \\
\hline ÖRGÜTSEL SESSIZLIKK & $\mathbf{2 , 2 5}$ & $\mathbf{0 , 7 5}$ \\
\hline
\end{tabular}

Genel olarak işgörenlerin kabullenici sessizlik düzeyi ise orta düzeyin altında $(\bar{X}=2,33)$ olduğu ulaşılan sonuçlar arasındadır. Bu boyutta yer alan ifadeler değerlendirildiğinde; işgörenlerin kendileri ile ilgili ve gelişime açık süreçlerle ilgili daha az sessiz kaldıkları, bunun dışındaki iş ve işleyiş ile ilgili ise sessiz kalmayı tercih ettikleri şeklinde yorumlanabilir. Literatürde Van Dyne vd. (2003) tarafından geliştirilen ölçeği kullanan araştırmalar ile araştırma sonucu karşılaştırıldığında, kabullenici sessizlik boyutuna ilişkin benzer sonuçlara ulaşıldığı görülmektedir (Eroğlu vd., 2011; Şimşek ve Aktaş, 2014; Ünlü vd., 2015; Karavardar, 2016). Genel olarak işgörenlerin savunmacı sessizlik düzeyinin orta düzeyin altında olduğu tespit edilmiştir ( $\bar{X}=2,09$ ). Ayrıca, Eroğlu vd. (2011), Şimşek ve Aktaş (2014) ile Ünlü vd. (2015)'nin savunmacı sessizlik boyutuna ilişkin araştırma sonuçları çalışma ile paralellik göstermektedir.

Otel işletmelerinde çalışan işgörenlerin sessizlik düzeyleri düşük olsa da örgüt ya da çalışma arkadaşlarının yararına bir durum söz konusuysa orta düzeyin üzerinde $(\bar{X}=3,68)$ sessiz kalmayı tercih ettiklerini belirtmişlerdir. Çalışmalarında aynı ölçeği kullanan araştırmalarda da diğer sessizlik alt boyutlarından farklı olarak bu boyuta ilişkin işgörenlerin sessizlik düzeylerinin daha yüksek olduğu belirtilmektedir (Eroğlu vd., 2011; Şimşek ve Aktaş, 2014; Ünlü vd., 2015). Bazı araştırmalarda ise, toplum yararına sessizlik düzeylerinin daha düşük olduğu sonucuna ulaşılmıştır (Karacaoğlu ve Küçükoğlu, 2015).

Otel işletmelerindeki işgörenlerin genel örgütsel sessizlik düzeylerinin ise, orta düzeyin altı olduğu ( $\bar{X}=2,33$ ) olduğu tespit edilmiştir. Araştırma sırasında aynı ölçeği (Van Dyne vd., 2003) kullanan araştırmaların sonuçları ile karşılaştırıldığında ise, uygulama alanı farklı olan bu araştırmalarda işgörenlerin sessizlik düzeylerinin daha yüksek olduğu (Şimşek ve Aktaş, 2014; Ünlü vd., 2015) belirtilmektedir. Genel olarak araştırma sonuçları, literatürde örgütsel sessizlik ile ilgili yapılan çalışmalar ile karşılaştırıldığında, araştırma sonuçlarını destekleyen çalışmaların (Çakıc1, 2008; Alparslan, 2010; Karabağ Köse ve Güçlü, 2017) yanı sıra, örgütsel sessizlik düzeylerinin yüksek olduğunu belirleyen araştırmalarda bulunmaktadır (Milliken vd., 2003; Nikmaram vd., 2012; Fatima vd., 2015; Karacaoğlu ve Küçükköylü, 2015). Turizm sektöründe ise 
örgütsel sessizliğe yönelik yapılan araştırma sonuçları da araştırmada elde edilen bulgularla paralellik göstermektedir (Altınöz vd., 2011; Kılıç vd., 2013; Kılıçlar ve Harbalıoğlu, 2014; Pelit vd., 2015; Pekerşen vd., 2016). Bunun yanı sıra literatürde, turizm sektöründe çalışanların sessizlik düzeylerinin yüksek olduğuna ilişkin araştırmalarda (Erol, 2015) bulunmaktadır.

Çatır (2015) tarafından otel işletmelerinde dönüşümcü ve etkileşimci liderliği örgütsel sessizlik üzerine etkisi ele alan araştırmada, işgörenlerin en fazla örgüt yararına sessizlik davranışını, daha sonra savunma amaçlı sessizlik davranışını, en son ise kabullenici sessizlik davranışını gerçekleştirdiklerini belirtmektedir. Otel işletmelerinin en fazla örgüt yararına sessizlik sergilediklerine ilişkin bulgular araştırma sonuçları ile benzerlik göstermektedir. Liderlik tarzının örgütsel sessizlik üzerindeki etkisinde örgütsel adaletin rolünü belirlemek amaciyla, İstanbul'da faaliyet gösteren beş yıldızlı otel işletmelerinde çalışan işgörenler üzerinde gerçekleştirilen araştırma sonuçlarına göre, işgörenlerin en fazla örgüt yararına sessizlik davranışı gösterdikleri belirtilmektedir (Taşkıran, 2010). Bu bulgular, araştırma sonuçlarını destekler niteliktedir. Ballı ve Çakıcı (2016) Türkiye'deki beş yıldızlı otel işletmelerinde çalışanların örgütsel bağlllı̆̆ının örgütsel sessizlik üzerindeki etkisini belirlemeye yönelik araştırmada da çalışanların örgüt yararına sessizlik düzeylerinin $(\bar{X}=4,22)$ diğer sessizlik boyutlarına göre daha yüksek olduğu vurgulanmaktadır. Araştırma sonuçları doğrultusunda, sektörlere göre farklılık gösterebilen bu davranış, turizm sektörünün özellikleri dikkate alındığında; hizmetin üretildiği anda tüketilme ve standardizasyonun zor olması gibi nedenlerden dolayı turizm işletmelerinin hizmet kalitesinin arttırılabilmesi ve rakiplerden farklılaşabilmesinde işgörenlerden gelen geri bildirim ve bilgi paylaşımının öneminden kaynaklandığı şeklinde yorumlanabilir. Tablo 2'de oteldeki işgörenlerin olumsuz durumları bildirme şekillerini belirlemeye yönelik olarak ankette yer alan her ifadesi için frekans, yüzde dağılımı, aritmetik ortalama ve standart sapma değerlerine yer verilmiştir.

Tablo 2. Olumsuz Durumları Bildirmenin Alt Boyutları ile İlgili Betimsel İstatistikler

\begin{tabular}{|l|c|c|}
\hline & $\overline{\mathrm{X}}$ & SS \\
\hline İçsel Bildirme & 3,89 & 1,21 \\
\hline Dişsal Bildirme & 2,87 & 1,29 \\
\hline Kimlikle Bildirme & 3,84 & 1,22 \\
\hline Gizli Bildirme & 2,01 & 1,17 \\
\hline Resmi Bildirme & 3,46 & 1,17 \\
\hline Gayri Resmi Bildirme & 2,88 & 1,34 \\
\hline GENEL ORTALAMA & $\mathbf{3 , 7 9}$ & $\mathbf{0 , 8 4}$ \\
\hline
\end{tabular}

İşgörenlerin olumsuz durumları bildirme düzeylerinin orta düzeyin $(\bar{X}=3,79)$ üzerinde olduğu tespit edilmiştir. Otel işletmesindeki işgörenlerin gözlemledikleri ya da fark ettikleri olumsuz, hatalı veya yanlış uygulamaları bildirdikleri şeklinde yorumlanabilir. Bildirim şekilleri değerlendirilecek olursa, katılımcıların içsel $(\bar{X}=3,89)$, kimlikle $(\bar{X}=3,84)$ ve resmi $(\bar{X}=3,46)$ olarak rapor etme ya da bildirme davranışını tercih ettikleri görülmektedir. Bu sonuçlar, örgütsel sessizlik ölçeğinde ulaşılan sonuçlarla birbirini destekler niteliktedir. 
İşörenlerin korku ya da bir fark yaratmayacağına dayalı olarak sessizleşme düzeylerinin düşük olması, işgörenlerin rahatlıkla fikirlerini ifade ettiğinin bir göstergesi olarak değerlendirilebilir. Ancak, sessiz kalmamaları olumsuz, hatalı veya yanlış uygulamaları bildirecekleri anlamına gelmemektedir. Ancak araştırmada elde edilen bulgular, işgörenlerin fikirlerini söyleme konusunda genel olarak sessizleşmeyi tercih etmediği gibi, uygulamalarda gözlemledikleri/fark ettikleri hatalı, yanlış ve olumsuz durumların düzeltilmesi için geri bildirim sağlamaktadır. Özellikle bu geri bildirimi gerçekleştirirken, genellikle işgörenlerin resmi yollarla, işletmedeki yetkililere kim olduklarını belirterek yapmayı tercih etmektedirler. Bu durumun, sektörün dinamik yapısı, işletmelerin sürekli değişime uyum sağlama zorunluluğu gibi unsurlardan kaynaklandığı düşünülebilir. Tüm bu unsurlar, turizm işletmelerindeki yöneticilerin bilgi ve geri bildirimin önemini ve sağladığı avantajların farkında olmasına katkı sağlamaktadır. Dolayısıyla, yöneticilerin işletmelerde sessizliğin değil de bilgi akışını destekleyen örgüt kültürünü desteklemesi ve yaygınlaştırmasıyla araştırma sonucunda elde edilen bulgulara her örgütte ulaşılabileceği şeklinde yorumlanmaktadır. Tablo 3 'te örgütsel dışlanmanın örgütsel sessizlik üzerindeki etkisine yönelik basit doğrusal regresyon analizi sonuçlarına yer verilmiştir.

Tablo 3. Örgütsel Dışlanmanın Örgütsel Sessizlik Üzerindeki Etkisi

\begin{tabular}{|l|c|c|c|c|c|c|}
\hline $\begin{array}{l}\text { Bağımsız } \\
\text { Değişkenler }\end{array}$ & $\boldsymbol{\beta j}$ & $\mathbf{S}(\mathbf{b j})$ & $\mathbf{t}$ & $\mathbf{p}$ & $\mathbf{F}$ & $\mathbf{p}$ \\
\hline Sabit & 1,761 & 0,044 & 40,053 & $0,000^{* * *}$ & \multirow{2}{*}{197,089} & $0,000^{* * * *}$ \\
\hline $\begin{array}{l}\text { Örgütsel } \\
\text { Dişlanma }\end{array}$ & 0,366 & 0,026 & 14,039 & $0,000^{* * *}$ & \\
\hline
\end{tabular}

${ }^{*} p<0,05 \quad{ }^{* * *} p<0,001$

Tablo 3'teki örgütsel dışlanmanın genel olarak örgütsel sessizlik üzerindeki etkisini belirlemeye yönelik basit doğrusal regresyon analizine ilişkin sonuçlara yer verilmiş olup, bulgular incelendiğinde uygulanan basit doğrusal regresyon analizinin uygun olduğu sonucuna ulaşılmıştır ( $F=197,089$ p <0,001). Örgütsel dışlanmanın örgütsel sessizlik üzerindeki etkisini belirlemeye yönelik regresyon modeli şu şekilde kurulabilir.

\section{Örgütsel Sessizlik = 1,761 + (0,366 x Örgütsel Dışlanma)}

$\mathrm{Bu}$ regresyon modeli değerlendirildiğinde, örgütsel dışlanmada gerçekleşen 1 birim artışın, örgütsel sessizlik üzerinde 0,366'lık bir artış yaratacağı regresyon modelinden saptanmıştır. Örgütteki işgörenlerin örgütsel sessizlik düzeyinin artmasında, örgütsel dışlanma algılarının etkili olduğu tespit edilmiştir. Ayrıca Kumral'ın (2017) yaptığı çalışmada, örgütsel dışlanmanın örgütsel sessizlik üzerinde daha güçlü bir etkisi $(\beta j=0,550)$ olduğunu tespit etmiştir. $B u$ doğrultusunda, araştırmanın temel hipotezinden biri olan, "Beş yıldızlı otel işletmelerinde çalı̧an işgörenlerin örgütsel dişlanma algzlarının örgütsel sessizlik düzeyleri üzerinde anlamlı bir etkisi vardır" Hipotez1 desteklenmiştir. Araştırmanın 1. hipotezi kapsamında oluşturulan alt hipotezler ile dışlanmanın örgütsel sessizliğin alt boyutları üzerindeki etkisini belirlemeye yönelik olup, Tablo 4,5 ve 6 'da basit doğrusal regresyon analizlerine ilişkin sonuçlara yer verilmiştir. 
Tablo 4. Örgütsel Dışlanmanın Örgütsel Sessizliğin Alt Boyutu Olan Kabullenici Sessizlik Üzerindeki Etkisi

\begin{tabular}{|l|c|c|c|c|c|c|}
\hline $\begin{array}{l}\text { Bağımsız } \\
\text { Değişkenler }\end{array}$ & $\boldsymbol{\beta j}$ & $\mathbf{S}(\mathbf{b j})$ & $\mathbf{t}$ & $\mathbf{p}$ & $\mathbf{F}$ & $\mathbf{p}$ \\
\cline { 1 - 5 } Sabit & 1,967 & 0,082 & 23,971 & $0,000^{* * * *}$ & \multirow{2}{*}{23,333} & $0,000^{* * * *}$ \\
\hline $\begin{array}{l}\text { Örgütsel } \\
\text { Dişlanma }\end{array}$ & 0,235 & 0,049 & 4,830 & $0,000^{* * * *}$ & \\
\hline
\end{tabular}

${ }^{*} p<0,05 \quad{ }^{* * *} p<0,001$

Tablo 4'te örgütsel dışlanmanın kabullenici sessizlik üzerindeki etkisini belirlemeye yönelik basit doğrusal regresyon analizinden yararlanılmıştır. Analiz sonucunda elde edilen bulgular incelendiğinde, uygulanan basit doğrusal regresyon analizinin uygun olduğu sonucuna ulaşılmıştır ( $\mathrm{F}=23,333 \mathrm{p}<0,001)$. Dışlanma algısının işgörenlerin kabullenici sessizlik davranışı sergilemelerinde etkili olduğu belirlenmiştir. Bu doğrultuda, örgütsel dışlanmanın örgütsel sessizliğin alt boyutu olan kabullenici sessizlik üzerindeki etkisini belirlemeye yönelik regresyon modeli şu şekilde kurulabilir.

\section{Kabullenici Sessizlik = 1,967 + (0,235 x Örgütsel Dışlanma)}

Bu regresyon modelleri değerlendirildiğinde ise, örgütsel dışlanmada gerçekleşen 1 birim artışın, kabullenici sessizlik üzerinde $0,235^{\prime}$ lik bir artış yaratacağ regresyon modelinde belirlenmiştir. Örgütsel dışlanmanın savunmacı sessizlik üzerindeki etkisine yönelik basit doğrusal regresyon analizi sonuçlarına Tablo 5 'te yer verilmiştir.

Tablo 5. Örgütsel Dışlanmanın Örgütsel Sessizliğin Alt Boyutu Olan Savunmacı Sessizlik Üzerindeki Etkisi

\begin{tabular}{|l|c|c|c|c|c|c|}
\hline $\begin{array}{l}\text { Bağı̆msız } \\
\text { Değişkenler }\end{array}$ & $\boldsymbol{\beta j}$ & $\mathbf{S}(\mathbf{b j})$ & $\mathbf{t}$ & $\mathbf{p}$ & $\mathbf{F}$ & $\mathbf{p}$ \\
\hline Sabit & 1,390 & 0,082 & 16,894 & $0,000^{* * * *}$ & \multirow{2}{*}{87,054} & $0,000^{* * * *}$ \\
\cline { 1 - 1 } $\begin{array}{l}\text { Örgütsel } \\
\text { Dişlanma }\end{array}$ & 0,455 & 0,049 & 9,330 & $0,000^{* * *}$ & \\
\hline
\end{tabular}

${ }^{*} p<0,05{ }^{* * *} p<0,001$

Örgütsel dışlanmanın savunmacı sessizlik üzerindeki etkisini belirlemeye yönelik basit doğrusal regresyon analizinden yararlanılmıştır. Bulgular doğrultusunda, uygulanan basit doğrusal regresyon analizinin uygun olduğu sonucuna ulaşılmıştır ( $F=87,054 p<0,001)$. Örgütsel dışlanmanın örgütsel sessizliğin alt boyutu olan savunmacı sessizlik üzerindeki etkisini belirlemeye yönelik regresyon modeli şu şekilde kurulabilir.

\section{Savunmacı Sessizlik = 1,390 + (0,455 x Örgütsel Dışlanma)}

Bu regresyon modelleri değerlendirildiğinde ise, örgütsel dışlanmada gerçekleşen 1 birim artışın, savunmacı sessizlik üzerinde $0,455^{\prime}$ lik bir artış yaratacağ regresyon modelinde tespit edilmiştir. Tablo 6'da örgütsel dışlanmanın örgüt yararına sessizlik üzerindeki etkisine yönelik basit 
doğrusal regresyon analizi sonuçları sunulmaktadır. Örgütsel dışlanmanın örgüt yararına sessizlik üzerindeki etkisini belirlemeye yönelik basit doğrusal regresyon analizinden yararlanılmıştır. Bulgular doğrultusunda, uygulanan basit doğrusal regresyon analizinin uygun olduğu sonucuna ulaşılmıştır ( $F=112,695 ; \mathrm{p}<0,001)$.

Tablo 6. Dışlanmanın Örgütsel Sessizliğin Alt Boyutu Olan Örgüt Yararına Sessizlik Üzerindeki Etkisi

\begin{tabular}{|l|c|c|c|c|c|c|}
\hline $\begin{array}{l}\text { Bağımsız } \\
\text { Değişkenler }\end{array}$ & $\boldsymbol{\beta j}$ & $\mathbf{S}(\mathbf{b j})$ & $\mathbf{t}$ & $\mathbf{p}$ & $\mathbf{F}$ & $\mathbf{p}$ \\
\hline Sabit & 4,485 & 0,083 & 53,999 & $0,000^{* * *}$ & \multirow{2}{*}{112,695} & $0,000^{* * * *}$ \\
\cline { 1 - 4 } $\begin{array}{l}\text { Örgütsel } \\
\text { Dişlanma }\end{array}$ & $-0,523$ & 0,049 & $-10,616$ & $0,000^{* * *}$ & \\
${ }^{*} p<0,0{ }^{* * *} p<0,001$ &
\end{tabular}

Örgütsel dışlanmanın örgütsel sessizliğin alt boyutu olan örgüt yararına sessizlik üzerindeki etkisini belirlemeye yönelik regresyon modeli şu şekilde kurulabilir.

\section{Örgüt Yararına Sessizlik = 4,485 + (-0,523 x Örgütsel Dışlanma)}

Bu regresyon modelleri değerlendirildiğinde ise, örgütsel dışlanmada gerçekleşen 1 birim artışın, örgüt yararına sessizlik üzerinde 0,523'luk bir azalış yaratacağı regresyon modellerinde belirlenmiştir. Örgütsel dışlanmanın örgütsel sessizlik üzerindeki etkisini belirlemeye yönelik yapılan araştırma kapsamında geliştirilen araştırma hipotezleri doğrultusunda uygulanan analizler ve bulgulara göre, örgütsel dışlanma ve örgütsel sessizlik ile arasında pozitif yönlü bir ilişki bulunmuş, regresyon analizi sonucunda ise örgütsel dışlanmanın örgütsel sessizlik düzeyini etkilediği sonucuna ulaşılmıştır. Elde edilen bulgular doğrultusunda alt hipotezler;

Kabullenici sessizlik üzerinde örgütsel dışlanmanın $\beta \mathbf{j}=0,235$ düzeyinde anlamlı bir etkisi olduğu belirlenmiş olup, "Otel işletmeleri işgörenlerinin örgütsel dışlanma algılarının kabullenici sessizlik düzeyleri üzerinde anlamlı bir etkisi vardır." ifade eden Hipotez1a desteklenmiştir.

Savunmacı sessizlik üzerinde örgütsel dışlanmanın $\beta \mathbf{j}=0,455$ düzeyinde anlamlı bir etkisi olmadığı belirlenmiş olup, "Otel işletmeleri işgörenlerinin örgütsel dışlanma algılarının savunmacı sessizlik düzeyleri üzerinde anlamlı bir etkisi vardır" ifade eden Hipotez1b araştırma sonucunda desteklenmiştir.

Örgüt yararına sessizlik üzerinde örgütsel dışlanmanın $\beta \mathbf{j}=-0,523$ düzeyinde anlamlı bir etkisi olduğu belirlenmiş olup, "Otel işletmeleri işgörenlerinin örgütsel dışlanma algılarının örgüt yararına sessizlik düzeyleri üzerinde anlaml bir etkisi vardır" ifade eden Hipotez1c desteklenmiştir. Bu doğrultusunda, araştırmanın temel hipotezini destekleyici nitelik taşıyan alt hipotezlerden Hipotez1a, Hipotez1b ve Hipotez1c desteklenmiştir.

Tablo 7'de örgütsel dışlanmanın olumsuz durumları bildirme üzerindeki etkisini belirlemeye yönelik basit doğrusal regresyon analizi sonuçlarına yer verilmiştir. Tablo 7 'de örgütsel dışlanmanın genel olarak olumsuz durumları bildirme üzerindeki etkisini belirlemeye yönelik basit doğrusal regresyon analizine ilişkin sonuçlara yer verilmiş olup, bulgular incelendiğinde uygulanan basit doğrusal regresyon analizinin uygun olduğu sonucuna ulaşılmıştır ( $F=246,244$; $\mathrm{p}<0,001)$. Örgütsel dışlanmanın olumsuz durumları bildirme üzerindeki etkisini belirlemeye yönelik regresyon modeli şu şekilde kurulabilir. 


\section{Olumsuz Durumları Bildirme =4,669 + (-0,569 x Örgütsel Dışlanma)}

$\mathrm{Bu}$ regresyon modeli değerlendirildiğinde, örgütsel dışlanmada gerçekleşen 1 birim artışın, olumsuz durumları bildirme üzerinde 0,569'luk bir azalış yaratacağı regresyon modelinden saptanmıştır. Bu doğrultusunda, araştırmanın temel hipotezinden biri olan, "Beş yıldızlı otel işletmelerinde çalışan işgörenlerin örgütsel dişlanma alg̨larının olumsuz durumları bildirme düzeyleri üzerinde anlamlı bir etkisi vardır" Hipotez2 desteklenmiştir.

Tablo 7. Örgütsel Dışlanmanın Olumsuz Durumları Bildirme Üzerindeki Etkisi

\begin{tabular}{|c|c|c|c|c|c|c|}
\hline $\begin{array}{l}\text { Bağımsı̆ız } \\
\text { Değişkenler }\end{array}$ & $\beta \mathbf{j}$ & $S(b j)$ & $\mathbf{t}$ & p & $\mathbf{F}$ & $p$ \\
\hline Sabit & 4,669 & 0,061 & 76,756 & $0,000^{* * *}$ & \multirow{2}{*}{246,244} & \multirow{2}{*}{$0,000^{* * * *}$} \\
\hline $\begin{array}{l}\text { Örgütsel } \\
\text { Dişlanma }\end{array}$ & $-0,569$ & 0,036 & $-15,692$ & $0,000^{* * *}$ & & \\
\hline
\end{tabular}

Araştırmanın 2. hipotezi kapsamında oluşturulan alt hipotezler ile dişlanmanın olumsuz durumları bildirmenin alt boyutları olan içsel, dışsal, gizli kimlikli, resmi ve gayri resmi bildirme üzerindeki etkisini belirlemeye yöneliktir. Tablo 8, 9, 10, 11, 12 ve $13^{\prime}$ te basit doğrusal regresyon analizlerine ilişkin sonuçlara yer verilmiştir.

Tablo 8. Örgütsel Dışlanmanın Olumsuz Durumları Bildirmenin Alt Boyutu Olan İçsel Bildirme Üzerindeki Etkisi

\begin{tabular}{|l|c|c|c|c|c|c|}
\hline $\begin{array}{l}\text { Bağı̆msız } \\
\text { Değişkenler }\end{array}$ & $\boldsymbol{\beta j}$ & $\mathbf{S ~ ( b j )}$ & $\mathbf{t}$ & $\mathbf{p}$ & $\mathbf{F}$ & $\mathbf{p}$ \\
\hline Sabit & 5,071 & 0,088 & 57,466 & $0,000^{* * * *}$ & \multirow{2}{*}{215,055} & $0,000^{* * * *}$ \\
\hline $\begin{array}{l}\text { Örgütsel } \\
\text { Dişlanma } \\
{ }^{*} p<0,05^{* * * *} p<0,001\end{array}$ & $-0,772$ & 0,053 & $-14,665$ & $0,000^{* * *}$ & \\
\hline
\end{tabular}

Tablo 8'de örgütsel dışlanmanın içsel bildirme üzerindeki etkisini belirlemeye yönelik basit doğrusal regresyon analizinden yararlanılmıştır. Basit doğrusal regresyon analizine ilişkin bulgular incelendiğinde, uygulanan basit doğrusal regresyon analizinin uygun olduğu sonucuna ulaşılmıştır $(F=215,055 ; p<0,001)$. Örgütsel dişlanmanın olumsuz durumları bildirmenin alt boyutu olan içsel bildirme üzerindeki etkisini belirlemeye yönelik regresyon modeli şu şekilde kurulabilir.

$$
\text { İçsel Bildirme = 5,071 + (-0,772 x Örgütsel Dışlanma) }
$$

Bu regresyon modelleri değerlendirildiğinde ise, örgütsel dışlanmada gerçekleşen 1 birim artışın, içsel bildirme üzerinde 0,772 'lik bir azalış yaratacağı regresyon modelinde belirlenmiştir. Tablo 9'da örgütsel dışlanmanın dışsal bildirme üzerindeki etkisini belirlemeye yönelik basit doğrusal regresyon analizinden yararlanılmıştır. 
Tablo 9. Örgütsel Dışlanmanın Olumsuz Durumları Bildirmenin Alt Boyutu Olan Dışsal Bildirme Üzerindeki Etkisi

\begin{tabular}{|l|c|c|c|c|c|c|}
\hline $\begin{array}{l}\text { Bağımsız } \\
\text { Değişskenler }\end{array}$ & $\boldsymbol{\beta j}$ & $\mathbf{S}(\mathbf{b j})$ & $\mathbf{t}$ & $\mathbf{p}$ & $\mathbf{F}$ & $\mathbf{p}$ \\
\cline { 1 - 4 } Sabit & 3,056 & 0,105 & 29,199 & $0,000^{* * * *}$ & \multirow{2}{*}{3,722} & 0,054 \\
\cline { 1 - 4 } $\begin{array}{l}\text { Örgütsel } \\
\text { Dişlanma }\end{array}$ & $-0,120$ & 0,062 & $-1,0929$ & 0,054 & \\
\hline
\end{tabular}

${ }^{*} p<0,05 \quad{ }^{* * *} p<0,001$

Basit doğrusal regresyon analizine ilişkin bulgular incelendiğinde, uygulanan basit doğrusal regresyon analizinin uygun olmadığ sonucuna ulaşılmıştır $(F=3,722 ; p<0,001)$. Bu regresyon analizi değerlendirildiğinde ise, örgütsel dişlanmanın kimlikle bildirme üzerinde anlamlı bir etkisi olmadığı tespit edilmiştir. Tablo 10' da örgütsel dışlanmanın kimlikle bildirme üzerindeki etkisini belirlemeye yönelik basit doğrusal regresyon analizinden yararlanılmıştır.

Tablo 10. Örgütsel Dışlanmanın Olumsuz Durumları Bildirmenin Alt Boyutu Olan Kimlikle Bildirme Üzerindeki Etkisi

\begin{tabular}{|c|c|c|c|c|c|c|}
\hline $\begin{array}{l}\text { Bağımsız } \\
\text { Değişkenler }\end{array}$ & $\beta \mathbf{j}$ & $S(\mathbf{b j})$ & $\mathbf{t}$ & $\mathrm{p}$ & $\mathbf{F}$ & $\mathrm{p}$ \\
\hline Sabit & 4,779 & 0,093 & 51,181 & $0,000^{* * * *}$ & \multirow[b]{2}{*}{121,376} & \multirow[b]{2}{*}{$0,000^{* * * *}$} \\
\hline $\begin{array}{l}\text { Örgütsel } \\
\text { Dışlanma }\end{array}$ & $-0,613$ & 0,056 & $-11,017$ & $0,000^{*+*+*}$ & & \\
\hline
\end{tabular}

${ }^{*} p<0,05 \quad{ }^{* * *} p<0,001$

Tablo 10'daki örgütsel dışlanmanın kimlikle bildirme üzerindeki etkisini belirlemeye yönelik basit doğrusal regresyon analizine ilişkin sonuçlara yer verilmiş olup, bulgular incelendiğinde uygulanan basit doğrusal regresyon analizinin uygun olduğu sonucuna ulaşılmıştır ( $F=121,376$; $\mathrm{p}<0,001)$. Örgütsel dişlanmanın olumsuz durumları bildirmenin alt boyutu olan kimlikle bildirme üzerindeki etkisini belirlemeye yönelik regresyon modeli şu şekilde kurulabilir.

\section{Kimlikle Bildirme $=4,779+(-0,613$ x Örgütsel Dişlanma $)$}

Bu regresyon modelleri değerlendirildiğinde ise, örgütsel dışlanmada gerçekleşen 1 birim artışın, kimlikle bildirme üzerinde $0,613^{\prime}$ luk bir azalış yaratacağı regresyon modelinde tespit edilmiştir. Tablo 11'de örgütsel dışlanmanın gizli bildirme üzerindeki etkisini belirlemeye yönelik basit doğrusal regresyon analizinden yararlanılmıştır.

Dışlanmanın gizli bildirme üzerindeki etkisini belirlemeye yönelik basit doğrusal regresyon analizine ilişkin bulgular incelendiğinde, uygulanan basit doğrusal regresyon analizinin uygun olduğu sonucuna ulaşılmıştır $(\mathrm{F}=84,100 ; \mathrm{p}<0,001)$. Örgütsel dışlanmanın olumsuz durumları bildirmenin alt boyutu olan gizli bildirme üzerindeki etkisini belirlemeye yönelik regresyon modeli şu şekilde kurulabilir.

\section{Gizli Bildirme = 1,251 + (0,495 x Örgütsel Dışlanma $)$}


Bu regresyon modelleri değerlendirildiğinde ise, örgütsel dışlanmada gerçekleşen 1 birim artışın, gizli bildirme üzerinde $0,495^{\prime}$ lik bir artış yaratacağı regresyon modellerinde belirlenmiştir. Tablo 12 'de örgütsel dışlanmanın resmi bildirme üzerindeki etkisini belirlemeye yönelik basit doğrusal regresyon analizinden yararlanılmıştır.

Tablo 11. Örgütsel Dışlanmanın Olumsuz Durumları Bildirmenin Alt Boyutu Olan Gizli Bildirme Üzerindeki Etkisi

\begin{tabular}{|l|c|c|c|c|c|c|}
\hline $\begin{array}{l}\text { Bağımsız } \\
\text { Değişkenler }\end{array}$ & $\boldsymbol{\beta j}$ & $\mathbf{S}(\mathbf{b j})$ & $\mathbf{t}$ & $\mathbf{p}$ & $\mathbf{F}$ & $\mathbf{p}$ \\
\cline { 1 - 5 } Sabit & 1,251 & 0,091 & 13,801 & $0,000^{* * * *}$ & \multirow{2}{*}{84,100} & $0,000^{* * *}$ \\
\cline { 1 - 4 } $\begin{array}{l}\text { Örgütsel } \\
\text { Dişlanma }\end{array}$ & 0,495 & 0,054 & 9,171 & $0,000^{* * *}$ & \\
\hline
\end{tabular}

${ }^{*} p<0,05 \quad{ }^{* * *} p<0,001$

Tablo 12. Örgütsel Dışlanmanın Olumsuz Durumları Bildirme Alt Boyutu Olan Resmi Bildirme Üzerindeki Etkisi

\begin{tabular}{|l|c|c|c|c|c|c|}
\hline $\begin{array}{l}\text { Bağımsız } \\
\text { Değişkenler }\end{array}$ & $\boldsymbol{\beta j}$ & $\mathbf{S}(\mathbf{b j})$ & $\mathbf{t}$ & $\mathbf{p}$ & $\mathbf{F}$ & $\mathbf{p}$ \\
\cline { 1 - 5 } Sabit & 4,062 & 0,092 & 43,979 & $0,000^{* * *}$ & \multirow{2}{*}{50,321} & $0,000^{* * * *}$ \\
\cline { 1 - 4 } $\begin{array}{l}\text { Örgütsel } \\
\text { Dişlanma }\end{array}$ & $-0,391$ & 0,055 & $-7,094$ & $0,000^{* * *}$ & \\
\hline
\end{tabular}

${ }^{*} p<0,05{ }^{* * *} p<0,001$

Örgütsel dışlanmanın resmi bildirme üzerindeki etkisini belirlemeye yönelik basit doğrusal regresyon analizine ilişkin Tablo 12 'de yer alan sonuçlar incelendiğinde, uygulanan basit doğrusal regresyon analizinin uygun olduğu sonucuna ulaşılmıştır $(F=50,321 ; p<0,001)$. Örgütsel dışlanmanın olumsuz durumları bildirmenin alt boyutu olan resmi bildirme üzerindeki etkisini belirlemeye yönelik regresyon modeli şu şekilde kurulabilir.

\section{Resmi Bildirme $=4,062+(-0,391$ x Örgütsel Dışlanma)}

Bu regresyon modelleri değerlendirildiğinde ise, örgütsel dışlanmada gerçekleşen 1 birim artışın, resmi bildirme üzerinde 0,391'lik bir azalış yaratacağı regresyon modelinde tespit edilmiştir. Tablo 13'te örgütsel dişlanmanın gayri resmi bildirme üzerindeki etkisini belirlemeye yönelik basit doğrusal regresyon analizi sonuçları sunulmaktadır.

Örgütsel dışlanmanın gayri resmi bildirme üzerindeki etkisini belirlemeye yönelik basit doğrusal regresyon analizine ilişkin Tablo 13'te yer alan sonuçlar incelendiğinde, uygulanan basit doğrusal regresyon analizinin uygun olmadığı sonucuna ulaşılmıştır $(F=0,001 ; p<0,001)$. Örgütsel dışlanmanın olumsuz durumları bildirmenin alt boyutu olan gayri resmi bildirme üzerinde anlamlı bir etkisi olmadığı belirlenmiştir. Örgütsel dışlanmanın olumsuz durumları bildirme eğilimi üzerindeki etkisini belirlemeye yönelik yapılan araştırma kapsamında geliştirilen araştırma hipotezleri doğrultusunda uygulanan analizler ve bulgulara göre, örgütsel dışlanma ve olumsuz durumları bildirme eğilimi ile arasında 0,454 negatif yönlü bir ilişki bulunmuş, 
regresyon analizi sonucunda ise örgütsel dışlanmanın olumsuz durumları bildirme eğilimini etkilediği sonucuna ulaşılmıştır. Elde edilen bulgular doğrultusunda alt hipotezler;

Tablo 13. Örgütsel Dışlanmanın Olumsuz Durumları Bildirmenin Alt Boyutu Olan Gayri Resmi Bildirme Üzerindeki Etkisi

\begin{tabular}{|l|c|c|c|c|c|c|}
\hline $\begin{array}{l}\text { Bağımsız } \\
\text { Değişkenler }\end{array}$ & $\boldsymbol{\beta j}$ & $\mathbf{S ~ ( b j ) ~}$ & $\mathbf{t}$ & $\mathbf{p}$ & $\mathbf{F}$ & $\mathbf{p}$ \\
\cline { 1 - 4 } Sabit & 2,879 & 0,109 & 26,473 & $0,000^{* * * *}$ & \multirow{2}{*}{0,001} & 0,972 \\
\cline { 1 - 4 } $\begin{array}{l}\text { Örgütsel } \\
\text { Dişlanma }\end{array}$ & 0,002 & 0,065 & 0,035 & 0,972 & 0,2 & \\
\hline
\end{tabular}

${ }^{*} p<0,05 \quad{ }^{* * *} p<0,001$

İçsel bildirme üzerinde örgütsel dişlanmanın $\beta \mathbf{j}=-0,772$ düzeyinde anlamlı bir etkisi olduğu belirlenmiş olup, "Otel işletmeleri işgörenlerinin örgütsel dışlanma algılarının içsel bildirme eğilimi üzerinde anlamlı bir etkisi vardır." ifade eden Hipotez2a desteklenmiştir.

Dışsal bildirme üzerinde örgütsel dışlanmanın $\beta \mathbf{j}=-0,120$ düzeyinde anlamlı bir etkisi olmadığ 1 belirlenmiş olup, "Otel işletmeleri işgörenlerinin örgütsel dışlanma alg̨larının dışsal bildirme eăilimi üzerinde anlamlı bir etkisi vardır" ifade eden Hipotez $2_{b}$ araştırma sonucunda desteklenmemiştir.

Kimlikle bildirme üzerinde örgütsel dışlanmanın $\beta \mathbf{j}=-0,613$ düzeyinde anlamlı bir etkisi olduğu belirlenmiş olup, "Otel işletmeleri işgörenlerinin örgütsel dışlanma algılarının kimlikle bildirme eğilimi üzerinde anlamlı bir etkisi vardır" ifade eden Hipotez2c desteklenmiştir.

Gizli bildirme üzerinde örgütsel dışlanmanın $\beta \mathbf{j}=0,495$ düzeyinde anlamlı bir etkisi olduğu belirlenmiş olup, "Otel işletmeleri işgörenlerinin örgütsel dışlanma algllarının gizli kimlikle bildirme eğilimi üzerinde anlamlı bir etkisi vardır" ifade eden Hipotez2 desteklenmiştir.

Resmi bildirme üzerinde örgütsel dışlanmanın $\beta \mathbf{j}=-0,391$ düzeyinde anlamlı bir etkisi olduğu belirlenmiş olup, "Otel işletmeleri işgörenlerinin örgütsel dışlanma algılarının resmi bildirme eğilimi üzerinde anlamlı bir etkisi vardır" ifade eden Hipotez2e desteklenmiştir.

Gayri Resmi bildirme üzerinde örgütsel dışlanmanın $\beta \mathbf{j}=0,002$ düzeyinde anlamlı bir etkisi olmadığı belirlenmiş olup, "Otel işletmeleri işgörenlerinin örgütsel dışlanma algılarının gayri resmi bildirme eăilimi üzerinde anlaml bir etkisi vardır" ifade eden Hipotez $2_{f}$ desteklenmemiştir. Bu doğrultusunda, araştırmanın temel hipotezini destekleyici nitelik taşıyan alt hipotezlerden Hipotez2a, Hipotez2c, Hipotez2d ve Hipotez2e desteklenirken, Hipotez2b ve Hipotez2 $f$ ise araştırma sonuçlarına göre desteklenmemiştir.

\section{SONUÇ ve ÖNERILLER}

Verimliliği arttırmak ve varlıklarını sürdürerek rekabet üstünlüğü kazanabilmek için örgütler entelektüel sermayesinden giderek daha fazla yararlanmakta ve örgütlerin temelini bilgi oluşturmaktadır. Bu doğrultuda, işgörenlerin, işletmedeki uygulama ve problemlerle ilgili bilgi, düşünce ve fikirlerini ifade etmesi yani işgörenlerin örgütsel ses ve içsel olumsuz durumları bildirmeye yönelik eğilimlerinin desteklenmesi önem taşımaktadır. 
Örgütsel dişlanmanın örgütsel sessizlik ve olumsuz durumları bildirme üzerindeki etkisini belirlemeye yönelik olarak basit analizleri uygulanmıştır. Örgütsel dışlanmada gerçekleşen 1 birimlik artışın örgütsel sessizlik üzerinde 0,366 etkiye neden olduğu belirlenmiştir. Örgütsel dışlanmanın en çok etki ettiği örgütsel sessizliğin alt boyutları incelendiğinde savunmacı sessizliğin artmasında, örgüt yararına sessizliğin ise azalmasında etkili olduğu belirlenmiştir. Bu sonuç doğrultusunda, araştırmanın temel hipotezini olan, "işgörenlerin örgütsel dışlanma algılarının örgütsel sessizlik düzeyleri üzerinde anlamlı bir etkisi vardır" hipotez1 desteklenmiştir. Elde edilen sonuç doğrultusunda, örgütsel dışlanma ve işgören tarafından algılanması, örgütsel sessizliğin ortaya çıkmasında etkili olan unsurlardan biri, farklı bir ifadeyle öncülerinden biri olduğu söylenebilir. Temel hipotez doğrultusunda, örgütsel dışlanmanın örgütsel sessizliğin alt boyutları olan; kabullenici sessizlik, savunmacı sessizlik ve örgüt yararına sessizlik üzerinde anlamlı etkisine yönelik olan hipotez1a, hipotez1b ve hipotez1c alt hipotezler de araştırma kapsamında desteklenmiştir.

Örgütsel dışlanmada gerçekleşen 1 birimlik artışın olumsuz durumları bildirme üzerinde -0,569 etkiye neden olduğu belirlenmiştir. Örgütsel dışlanmanın olumsuz durumları bildirmenin alt boyutları arasında en çok etki ettiği boyutlar değerlendirildiğinde ise, örgütsel dışlanmanın içsel bildirme $(-0,772)$, kimlikle bildirme $(-0,613)$ ve resmi bildirmenin $(-0,391)$ azalmasında etkili olduğu belirlenmiştir. Ayrıca, örgütsel dışlanmanın gizli bildirme $(0,495)$ artmasında etkili olduğu sonucuna ulaşılmıştır. Bu sonuç doğrultusunda, araştırmanın temel hipotezini olan, "işgörenlerin örgütsel dışlanma algılarının olumsuz durumları bildirme üzerinde anlamlı bir etkisi vardır" hipotez2 desteklenmiştir. Elde edilen sonuç doğrultusunda, örgütsel dışlanma ve işgören tarafından algılanması, olumsuz durumların bildirilmesinin örgüt içinde ortaya çımasını olumsuz yönde etkilemektedir. Temel hipotez doğrultusunda, örgütsel dışlanmanın olumsuz durumları bildirmenin alt boyutları olan; içsel bildirme, dışsal bildirme, kimlikle bildirme, gizli bildirme, resmi bildirme ve gayri resmi bildirme üzerinde anlamlı etkisine yönelik olan hipotez2a, hipotez2b, hipotez2c, hipotez2d, hipotez2e ve hipotez2f alt hipotezler de araştırma kapsamında desteklenmiştir.

Bu çalışma, işgörenlerin örgütsel dışlanma algılarını azaltmak ve örgütte gözlemlenen örgütsel dışlanmaların işgörenlerin sessizlik ve olumsuz durumları bildirme eğilimleri üzerindeki etkisini belirtmektir. İşgörenin, çalışma arkadaşları tarafından görmezden gelinmesi ya da yok sayılması; gruba uyum sağlamak için işgörenin daha fazla çaba ve performans sergilemesine neden olabileceği gibi, işgörenin grupla çatışma sürecine girerek durumun daha olumsuz sonuçlanması da ortaya çıkabilecek sonuçlar arasında yer almaktadır. Dışlanmışlık algısına sahip olan bireyler gruba uyum sağlama sürecinde, dikkat çekmemek ya da başkalarını hedef haline getirmek için kabullenici ya da savunmacı temelli olarak sessizlik davranışı sergileyeceklerdir. Bunun yanı sıra grupla çatışma sürecinde olan dışlanmış bireyler, olumsuz durumları bildirme davranışını örgüt içinde gerçekleştirmek yerine kin, öfke, intikam ve kendini kanıtlama gibi nedenlerle/amaciyla dış kurum ve kuruluşlara bildirim eğilimi göstermelerine neden olabilmektedir. Bu durum işletme açısından itibar kaybı, maddi değeri yüksek cezalar, sadık müşterilerin kaybedilmesi ve nitelikli işgücünün o işletmede çalışmak istememesi gibi uzun vadede işletmenin performans ve etkinlik düzeyini olumsuz yönde etkileyebilecek sonuçlar oluşturabilir. Dolayısıyla, kendini dışlanmış olarak algılayan ya da hisseden işgörenler örgüte katkı sağlayacak olumsuz geri bildirimler gerçekleştirmeyecekleri gibi, sessizleşmelerinin de artmasında etkili olacaktır. Bulgular doğrultusunda otel işletmelerinin sahip olduğu nitelikli işgücünü işletmede kalması, etkili iletişim ortamının yaygınlaşmasının yanı sıra özgün ve sistemin içinden geri dönüt ya da bilgi akışı sağlayarak; işletmenin hizmet kalitesi ve müşteri memnuniyetini arttırabilmesi ile birlikte işgörenlerin örgütle özdeşleşme, bağlılık ve örgütsel vatandaşlık düzeylerinde de artışın 
sağlanabilmesi için konuyla ilgili literatüre ve araştırmacılara katkı sağlaması bakımından aşağıdaki öneriler geliştirilmiştir.

- İsgörenlerin işletme açısından yarattığı çarpan etkisinin yönetim tarafından fark edilmesiyle birlikte, işgörenleri olumsuz etkileyen unsurların belirlenerek, bu unsurların azaltılması ya da ortaya çıkmasını engellemeye yönelik uygulama ve politikalar geliştirilmektedir. Önemli bir bilgi kaynağı ve strateji geliştirilmesinde etkili olan olumsuz durumların bildirilmesi ve işgörenlerin görüş, düşünce ve fikirlerini açıkça yöneticileri ve çalışma arkadaşlarıyla paylaşabilmesi ile ilgili olan olumsuz durumları bildirme ve örgütsel sessizlik davranışları ve bu davranışların ortaya çıkmasında etkili olabilecek değişkenlerden biri olan örgütsel dişlanma ile ilgili sınırlı çalışmanın bulunmasının yanı sıra turizm işletmelerine araştırma modeli doğrultusunda literatürde çalışma ile karşılaşılmamıştır. Özellikle turizm işletmelerinde örgütsel dışlanma ve olumsuz durumları bildirme eğilimi ile ilgili araştırmaların artmasına katkı sağlayacaktır.

- Yönetim ve insan kaynakları departmanı tarafından düzenli ve belli aralıklarla işgörenlerin katılımı ile oynanan takım oyunlarının düzenlenmesi ve bu süreçte takım oyunlarında tercih edilmeyen işgörenlerin tespit edilmesi sağlanabilir. Literatürde örgütsel dişlanma ile ilgili yapılan deneysel araştırmalarda dışlanan bireyler basit oyunlar aracılı̆̆ıyla tespit etmektedir. Dolaysıyla, düzenlenen bu oyunlar grup tarafından kabul gören bireylerin anlaşılmasını sağlayacă̆ı gibi, grup tarafından dışlanan işgörenlerin de gözlemlenmesini sağlayacaktır.

- Dişlanmış işgörenlerin belirlenmesinde, örgüt tarafından düzenlenen drama dersleri aracılığıyla bireyin yaşadığı duygusal yoğunluk ya da tepkilerini sergileme imkanı sunulabilir. Ancak bu doğaçlama şeklinde gerçekleştirilen dram derslerine dışarından uzman bir psikolojik danışmanın gözlemlemesi, sonrasında dışlanmışlık algısına sahip ya da grup tarafından dışlanan bireylere psikolojik destek verilmesi açısından önem taşımaktadır.

- Dışlanma, bireyin özsaygısının azalması ve varoluşunun anlamını yitirmesine neden olmakta olup, bu duyguların güçlendirilebilmesi için örgütte kişisel gelişim ile ilgili kurslarla işgörenler desteklenebilir.

- İletişimin ortadan yok olması ya da iletişim bozuklukları ile ilişkili olan dışlanma kavramının örgütlere nüfus etmesi engellemek için, iletişim becerilerini geliştirmeye yönelik sanal ya da yerinde seminer eğitimleri gerçekleştirmesi de katkı sağlayacaktır.

- Turizm işletmelerinde sezon açılışı ve sezon bitişinde düzenlenen moral aktiviteleri de sosyal alanlar yarattığı için dışlanma algısının azalmasına katkı sağlayabilir.

- Gruptan ya da baskın kültürden farklı düşünce ve fikirlere sahip olduğunu ifade eden işgörenler dışlanmaya maruz kalabilmektedir. Hem dışlanmanın yaşanmaması hem de değerli bilgi niteliği taşıyan geri bildirim ve fikirlerini diğerleri ne düşünür, nasıl tepki verir ya da eğer söylersem acaba olumsuz tepkiyle karşılaşır mıyım gibi endişeler olmadan, rahatlikla açıklayabileceği sistemlerin işletme içerisinde yaygınlaştırılması gerekmektedir. Özellikle teknolojinin gelişmesi geri bildirim ve işgörenlerin isimsiz olarak yönetim kademesini fikirlerini iletebilecekleri yazılımların oluşturulmasını hem maddi olarak kolaylaştırmakta hem de işgörenler tarafından kullanımı açısından da kolay benimsenmesine imkan sunacaktır.

- Araştırma İstanbul ve Kuşadası faaliyet göstermekte olan beş yıldızlı otel işletmesinde çalışan 957 işgörenlerle sınırlıdır. Daha sonra yapılacak olan araştırmalarda farklı turizm işletme türleri (üç ve dört yıldızlı otel işletmeleri, seyahat acentaları, yiyecek içecek işletmeleri, vb.) araştırmaya dahil edilebileceği gibi, emek yoğun özellik taşıyan diğer hizmet işletmelerinde de örgütsel dışlanmanın örgütsel sessizlik ve olumsuz durumları bildirme eğilimine olan etkisinin belirlenmesi, hem konunun tüm turizm sektörü açısından değerlendirilmesine hem de hizmet işletmelerinde farklı durum ve sonuçların ortaya konulmasına önemli katkılar sağlayacaktır. 
Genel olarak araştırma sonuçları değerlendirildiğinde, işletmelerin belirledikleri misyon ve vizyonları gerçekleştirmesinden en önemli katkıyı sağlayan işgörenlerin düşünce, fikir ve önerilerini paylaşmalarının yanı sıra işten ayrılma niyetlerini, örgütsel bağlılık, örgütsel özdeşleşme ve örgütsel vatandaşlık düzeylerini olumsuz etkileyebilecek olan unsurların tespit edilmesi gerekmektedir. Özellikle hizmet işletmelerinde sunulan ürünün kalitesi ve müşteri memnuniyet düzeyi işgörenler ile doğrudan etkileşim içerisindedir. Bu bağlamda, işgörenleri ve takım çalışmasını olumsuz yönde etkileyebilecek olan örgütsel dışlanma ve sessizlik gibi faktörlerin dikkate alınarak, çözüme yönelik uygulama ve politikaların geliştirilmesi gerekmektedir. Çalışma arkadaşları tarafından görmezden gelinme ya da yok sayılma korkusu olmayan ya da yöneticileri tarafından kariyer ve terfi gibi durumların olumsuz yönde değerlendirileceği algısına sahip olmayan işgörenlerin fikir, düşünce ve önerilerini paylaştığı gibi, örgüt içerisinde gerçekleşen gözlemlediği olumsuz durumlar hakkında da bilgi verme eğiliminde artış sağlanacaktır. Bireylerin sergiledikleri davranışlar sonucunda katlanacağı sonuç ve etkileri değerlendirerek, davranışlarını gerçekleştirdiği düşünüldüğünde olumsuz algı bu davranışların gerçekleşmesindeki en önemli engellerden biri niteliğindedir. Araştırma sonucunda, örgütsel dışlanmanın örgütsel sessizlik ve olumsuz durumları bildirme eğilimi üzerinde orta düzeyin altında etkisi dikkate alındığında, yöneticilerin olumsuz nitelikli bu davranışın örgüt içinde yaygınlaşmasını engellemek ya da azaltabilmek için yönetimin uygulamaya yönelik alacağı karar ve uygulamalar ile diğer işletmelerde farklılaşarak, rekabet üstünlügü sağlamasında önemli katkılar sağlayabilecek bilgi ve geri bildirimin örgüt içinde yaygınlaşmasına katkı sağlayacaktır.

\section{KAYNAKÇA}

Ağaoğlu, O.K. (1992). İşgücünü Verimli Kullanma Tekniklerinin Turizm Sektörüne Uygulanmas1, Verimlilik Dergisi, 110-121.

Aktaş, H. ve Şimşek, E. (2015). Bireylerin Örgütsel Sessizlik Tutumlarında İş Doyumu ve Duygusal Tükenmişlik Algılarının Rolü, Uluslararası Yönetim İktisat ve İşletme Dergisi, 11(24): 205230.

Alparslan, A.M. (2010). Örgütsel Sessizlik İklimi ve İşgören Sessizlik Davranışları Arasındaki Etkileşim: Mehmet Akif Ersoy Üniversitesi Öğretim Elemanları Üzerinde Bir Araştırma, Yayınlanmamış Yüksek Lisans Tezi, Süleyman Demirel Üniversitesi Sosyal Bilimler Enstitüsü, Isparta.

Altınöz, M., Çöp, S. ve Kervancl, F. (2011). Örgütsel Sessizlik ve Örgütsel Güven İlişkisi: Ankara'daki Dört ve Beş Yıldızlı Otel İşletmeleri Üzerine Bir Araştırma, 12. Ulusal Turizm Kongresi, Düzce: 582-590.

Ateş, H., Bağce, H.E. ve Şen, M.L. (2009). Yolsuzluğun Önlenmesi için Etik Projesi, Kamu Etiği Akademik Araştırmaları, 1: 12-102.

Ballı, E. ve Çakıcı, A. (2016). Otel İşletmelerinde Çalışanların Örgütsel Bağlllı̆̆ının Örgütsel Sessizlikleri Üzerindeki Etkisi, Çukurova Üniversitesi İktisadi İdari Bilimler Fakülte Dergisi, 20(2): 7998.

Barry, B. (2007). The Cringing and The Craven: Freedom of Expression in Around and Beyond the Workplace, Business Ethics Quarterly, 17(2): 263-296.

Baumeister, R.F. and Tice, D.M. (1990). Anxiety and Social Exclusion, Journal of Social and Clinical Psychology, 9: 165-195. 
Bayın, G., Yeşilaydın, G. and Esatoğlu, A.E. (2015). Determination of Reasons for Organizational Silence of Nurses, İşletme Araştırmaları Dergisi, 7(1): 248-266.

Bayrakçı, E. ve Kayalar, M. (2016). Örgütsel Bağlllık Düzeylerine Göre İfşa Davranışının Nitel Araştırmayla İncelenmesi, Journal of Current Researches on Business and Economics, 6(1): 15-42.

Bildik, B. (2009). Liderlik Tarzları, Örgütsel Sessizlik ve Örgütsel Bağlllık İlişkisi, Yayınlanmamış Yüksek Lisans Tezi, Gebze Yüksek Teknoloji Enstitüsü Sosyal Bilimler Enstitüsü, Gebze.

Blackhart, G.C., Knowles, M.L., Nelson, B.C., and Baumeister, R.F. (2009). Rejection Elicits Emotional Reactions but Neither Causes Immediate Distress nor Lowers Self-Esteem: A MetaAnalytic Review of 192 Studies on Social Exclusion. Pers. Soc. Psychol. 13: 269-309.

Callahan, E.S. and Collins, J.W. (1992). Employee Attitudes Toward Whistleblowing: Management and Public Policy Implications, Journal of Business Ethics, 11(12): 939-948.

Chow, R.M., Tiedens, L.Z. and Govan, C.L. (2008). Excluded Emotions: The Role of Anger in Antisocial Responses to Ostracism, Journal of Experimental Social Psychology, 44(3): 896-903.

Çakıcı, A. (2007). Örgütsel Sessizlik: Sessizliğin Teorik Temelleri ve Dinamikleri, Ç.Ü. Sosyal Bilimler Enstitüsü Dergisi, 16(1): 145-162.

Çakıcı, A. (2008). Örgütlerde Sessizlik Tercihi ve Sessizlik Türleri, (Editör) Solmuş, T.: İş ve Özel Yaşama Psikolojik Bakışlar içinde (85-109), İstanbul: Epsilon Yayınları.

Çakıcı, A. ve Çakıcı, C. (2007). İşgören Sessizliği: Konuşmak Mı Zor, Sessiz Kalmak Mı Zor?, 15. Ulusal Yönetim ve Organizasyon Kongresi, Sakarya: 389-400.

Çatır, O. (2015). Dönüşümcü ve Etkileşimci Liderliğin Örgütsel Sessizlik Üzerine Etkisi: Otel İşletmelerinde Bir Uygulama, Yayınlanmamış Doktora Tezi, Gazi Üniversitesi Eğitim Bilimleri Enstitüsü, Ankara.

Çiğdem, S. (2013). Büro Yönetiminde Whistleblowing ve Etik İlişkisi, Süleyman Demirel Üniversitesi Sosyal Bilimler Enstitüsü Dergisi, Büro Yönetimi Özel Sayısı: 93-109.

Ehtiyar, R. and Yanardağ, M. (2008). Organizational Silence: A Survey on Employees Working in a Chain Hotel, Tourism and Hospitality Management, 14(1): 51-68.

Erdoğan, E. (2011). Etkili Liderlik Örgütsel Sessizlik ve Performans İlişkisi, Yayınlanmamış Yüksek Lisans Tezi, Gebze Yüksek Teknoloji Enstitüsü Sosyal Bilimler Enstitüsü, Gebze.

Eroğlu, A.H., Adıgüzel, O. ve Öztürk, U.C. (2011). Sessizlik Girdabı ve Bağlılık İkilemi: İşgören Sessizliği ile Örgütsel Bağlllık İlişkisi ve Bir Araştırma, Süleyman Demirel Üniversitesi İktisadi ve İdari Bilimler Fakültesi Dergisi, 16(2): 97-124.

Erol, G. (2015). Örgütsel Sessizliğin Nedenleri Üzerine Nitel Bir Yaklaşım: Otel İşletmeleri Örneği, I. Eurasia International Tourism Congress: Current Issues, Trends and Indicators, Konya: 129137.

Fatima, A. Salah-Ud-Din, S., Khan, S., Hassan, M. and Hoti, H.A.K. (2015). Impact of Organizational Silence on Organizational Citizenship Behavior: Moderating Role of Procedural Justice, Journal of Economics, Business and Management, 3(9): 846-850.

Fatima, T., Ilyas, M., Rehman, C.A. and Imran, M.K. (2017). Empirical Investigation of Relationship between Workplace Ostracism and Employee Silence: A Test of Mediating Effects of Self-Esteem and Meaningful Existence in Context of Public Sector Universities in Punjab, Abasyn Journal of Social Sciences, 10(1): 111-128. 
Ferris D.L. Brown D.J. Berry J.W. and Lian H. (2008). The Development and Validation of the Workplace Ostrasicm Scale, The Journal of Applied Psychology, 93: 1348-1366.

Finne, L.B., Knardahl, S. and Lau, B. (2011). Workplace Bullying and Mental Distress - A Prospective Study of Norwegian Employees, Scandinavian Journal of Work, Environment $\mathcal{E}$ Health, 37(4): 276-287.

Ford, M.B. and Collins, N.L. (2010). Self-Esteem Moderates Neuroendocrine and Psychological Responses to Interpersonal Rejection, Journal of Personality and Social Psychology, 98(6): 955.

Gkorezis, P., Panagiotou, M. and Theodorou, M. (2016). Workplace Ostracism and Employee Silence in Nursing: The Mediating Role of Organizational Identification, Journal of Advanced Nursing, 72(10): 2381-2388.

Gül, H. ve Özcan, N. (2011). Mobbing ve Örgütsel Sessizlik Arasındaki İlişkiler: Karaman İl Özel İdaresinde Görgül Bir Çalışma, Kahramanmaraş Sütçü İmam Üniversitesi İktisadi ve İdari Bilimler Fakültesi Dergisi, (1-2): 107-135.

Haq, I.U. (2014). Workplace Ostracism and Job Outcomes: Moderating Effects of Psychological Capital, Management, Knowledge and Learning International Conference, 25-27 June 2014 Portoroz- Slovenia. ss: 1309-1323.

Hitlan, R. T., Kelly, K.M., Schepman, S., Schneider, K.T. and Zarate, M.A. (2006). Language Exclusion and The Consequences of Perceived Ostracism in the Workplace, Group Dynamics: Theory, Research, And Practice, 10(1): 56-70.

Hitlan, R. and Noel, J. (2009). The Influence of Workplace Exclusion and Personality on Counterproductive Work Behaviours: An Interactionist Perspective, European Journal of Work and Organizational Psychology, 18(4): 477-502.

Huang, X., Vliert E. and Der Vegt, G.V. (2005). Breaking the Silence Culture: Stimulation of Participation and Employee Opinion Withholding Cross-Nationally, Management and Organization Review, 1(3): 459-482.

İlçe Kültür ve Turizm Müdürlüğü. (2016). Turizm Belgeli Tesis İstatistikleri. Aydın: İl Kültür ve Turizm Müdürlüğü.

Jones, E.E., Carter, A. R., Kelly, J.R. and Williams, K.D. (2009). I'm Out of the Loop': Ostracism Through Information Exclusion, Group Processes \& Intergroup Relations, 12(2): 157-174.

Kahya, C. (2013). Dönüştürüıü ve Etkileşimci Liderlik Anlayışları ile Örgütsel Sessizlik Arasındaki İlişkide Örgütsel Güvenin Rolü, Atatürk Üniversitesi Sosyal Bilimler Enstitüsü, Erzurum.

Karabağ Köse, E. and Güçlü, N. (2017). Examining the Relationship between Leadership Styles of School Principals, Organizational Silence and Organizational Learning, International Online Journal of Educational Sciences, 9(1): 129-140.

Karacaoğlu, K. ve Cingöz A. (2009). İşgören Sessizliğinin Kaynağı Olarak Liderlik Davranışı ve Örgütsel Adalet Algısı. Sözel Bildiri, 17. Ulusal Yönetim ve Organizasyon Kongresi, Osmangazi Üniversitesi, 21-23 Mayıs, Eskişehir: 698-705.

Karacaoğlu, K. ve Küçükköylü, C. (2015). İşgören Sessizliğinin Örgütsel Sinizme Etkisi: Kamu Çalışanları Üzerine Bir Araştırma, Ege Akademik Bakış Dergisi, 15(3): 401-408.

Karasar, N. (2008). Bilimsel Araştırma Yöntemi, Ankara: Nobel Yayın Dağıtım.

Karavardar, A. (2016). İç Kontrol Sisteminin Örgüt İklimi Üzerindeki Etkisi, Sözel Bildiri, 15. Ulusal İşletmecilik Kongresi, İstanbul: 143-151. 
Kılıç, G., Tunç, T., Saraçlı, S. ve Kılıç, İ. (2013). Örgütsel Stresin Örgütsel Sessizlik Üzerine Etkisi: Beş Yıldızlı Termal Otel İşletmelerinde Bir Uygulama, İşletme Araştırmaları Dergisi, 5(1): 17-32.

Kılıçlar, A. ve Harbalığlu, M. (2014). Örgütsel Sessizlik ve Örgütsel Vatandaşlık Davranışı Arasındaki İlişki: Antalya'daki Beş Yıldızlı Otel İşletmeleri Üzerine Bir Araştırma, İşletme Araştırmaları Dergisi, 6(1): 328-346.

Kumral, T. (2017). İşyeri Nezaketsizliği ve Örgütsel Sessizlik İlişkisinde Örgütsel Dışlanmanın Aracı Rolü, Yayınlanmamış Yüksek Lisans Tezi, Marmara Üniversitesi Sosyal Bilimler Enstitüsü, İstanbul.

Kültür ve Turizm Bakanlığı. (2015). Turizm Belgeli Tesis İstatistikleri. Ankara: Kültür ve Turizm Bakanlığı Yatırım ve İşletmeler Genel Müdürlüğü Araştırma ve Değerlendirme Daire Başkanlığı.

Kültür ve Turizm Bakanlığı. (2017). Turizm Belgeli Tesis İstatistikleri. Ankara: Kültür ve Turizm Bakanlığı Yatırım ve İşletmeler Genel Müdürlüğü Araştırma ve Değerlendirme Daire Başkanlığı.

Leary, M.R., Koche, E.J. and Hechenbleikner, N.R. (2001). Emotional Responses to Interpersonal Rejection, (Editör) Leary, M. R., Interpersonal Rejection, Oxford Press, New York: 145-166.

Leung, A.S.M., Wu, L.Z., Chen, Y.Y. and Young, M.N. (2011). The Impact of Workplace Ostracism in Service Organizations, International Journal of Hospitality Management, 30: 836- 844.

Liu, J. and Wang, W. (2011). Employee Behavior Supervisor-Subordinate Quanxi and Workplace Exclusion. 2011 International Conference on Management and Service Science: 1-15.

Lustenberger, D.E. and Jagacinski, C.M. (2010). Exploring the Effects of Ostracism on Performance and Intrinsic Motivation, Human Performance, 23(4): 283-304.

Miceli, M.P. and Near, J.P. (1984). The Relationships Among Beliefs, Organizational Position, and Whistle-Blowing Status: A Discriminant Analysis, The Academy of Management Journal, 27(4): 687705.

Miceli, M.P., Van Scotter, J.R., Near, J.P. and Rehg, M.T. (2001). Individual Differences and Whistle-Blowing, Academy of Management Annual Meeting Proceedings, 1-6.

Milliken, F.J. and Morrison, E.W. (2003). Shades of Silence: Emerging Themes and Future Directions for Research on Silence in Organizations, Journal of Management Studies, 40(6): 15631568.

Milliken, F.J., Morrison, E.W. and Hewlin, P.F. (2003). An Exploratory Study of Employee Silence: Issues That Employees Don't Communicate Upward and Why, Journal of Management Studies, 40(6): 1453-1476.

Morrioson, E.W. and Milliken F.J. (2000). Organizational Slience: A barrier to Change and Development in a Pluralistic World, The Academy of Management Review, 25(4): 706-725.

Nikmaram, S., Yamchi, H.G., Shojaii, S., Zahrani, M.A. and Alvani, S.M. (2012). Study on Relationship Between Organizational Silence and Commitment in Iran, World Applied Sciences Journal, 17(10): 1271-1277.

O'Reilly, J. and Robinson, S.L. (2009). Ostracism at Work: The Impact of Ostracism on Thwarted Belongingness and Work Contributions. The Annual Meeting of The Academy of Management, Chicago, IL.

Özdamar, K. (2001). Paket Programlar ve İstatistiksel Veri Analizi (Çok Değişkenli Analizler) (4. Baskı), Eskişehir: Kaan Yayınları. 
Özgen I. ve Sürgevil, O. (2009). Örgütsel Sessizlik Olgusu ve Turizm İşletmeleri Açısından Değerlendirilmesi, (Editör) Sabuncuoğlu, Z.: Turizm İ̧̧letmelerinde Örgütsel Davranış içinde, Bursa: MKM Yayıncilı.

Park, H., Blenkinsopp, J., Oktem, M.K. and Ömürgönülşen, U. (2008). Cultural Orientation and Attitudes Toward Different from of Whistleblowing: A Comparison of South Korea, Turkey and the U.K., Journal of Business Ethics, 82: 929-939.

Park, H., Rehg, M.T. and Lee, D. (2005). The Influence of Confucian Ethics and Collectivisim on Whistleblowing Intentions: A Study of South Korean Public Employee, Journal Business Ethics, 58: 387-403.

Pekerşen, Y., Çakır Keleş, M. ve Ata Kuduban, Ş.D. (2016). Otel İşletmeleri İşgörenlerinin Örgütsel Sessizlik Düzeyleri Üzerine Bir Araştırma: Trabzon, Ordu ve Giresun İllerindeki 3, 4 ve 5 Yıldızlı Otel İşletmeleri Örneği, Çatalhöyük Uluslararası Turizm ve Sosyal Araştırmalar Dergisi, 1: $301-320$

Pelit, E. (2008). İşletmelerde İşgören Güçlendirmenin İşgörenlerin İş Doyumuna Etkisi: Otel Işsletmelerinde Bir Araştırma, Yayınlanmamış Doktora Tezi, Gazi Üniversitesi Eğitim Bilimleri Enstitüsü, Ankara.

Pelit, E., İstanbullu Dinçer, F. and Kılıç, İ. (2015). The Effect of Nepotism on Organizational Silence, Alienation and Commitment: A Study on Hotel Employees in Turkey, Journal of Management Research, 7(4): 82-110.

Premeaux, S.F. (2001). Breaking the Silence: Toward an Understanding of Speaking Up in the Workplace, Doktora Tezi, Loisiana State Üniversitesi, Amerika Birleşik Devletleri.

Renn, R., Allen, D. and Huning, T. (2013). The Relationship of Social Exclusion at Work with SelfDefeating Behavior and Turnover, J. Soc. Psychol. 153: 229-249.

Sayğan, F.N. (2011). Relationship Between Affective Commitment and Organizational Silence: A Conceptual Discussion, International Journal of Social Sciences and Humanity Studies, 3(2): 219-227.

Seibert, S.E., Kraimer, M.L. and Liden, R.C. (2001). A Social Capital Theory of Career Success, Academy of Management Journal, 44(2): 219-237.

Şimşek, E. (2011). Örgütsel İletişim ve Kişilik Özelliklerinin Yaşam Doyumuna Etkileri, Doktora Tezi, Anadolu Üniversitesi, Eskişehir.

Şimşek, E. and Aktaş, H. (2014). The Interactions of Organizational Silence with Personality and Life Satisfaction: A Research on Public Sector, Anadolu University Journal of Social Sciences, 14(2): 121-136.

Taşkıran, E. (2010). Liderlik Tarzının Örgütsel Üzerindeki Etkisinde Örgütsel Adaletin Rolü ve Bir Araştırma, Marmara Üniversitesi Sosyal Bilimler Enstitüsü, Doktora Tezi, İstanbul.

Turizm Bakanlığı. (1989). Otelcilik ve Turizm Endüstrisinde İşgücü Araştırması. Ankara: Turizm Bakanlığı Yayınları.

Ural, A. ve Kılıç, İ. (2010). Bilimsel Araştırma Süreci ve SPSS İle Veri Analizi (SPSS 10.00 - 12.0 for Windows) (6. Basım), Ankara: Detay Yayıncılık.

Ülker, F. ve Kanten, P. (2009). Örgütlerde Sessizlik İklimi, İşgören Sessizliği ve Örgütsel Bağlllık İlişkisine Yönelik Bir Araştırma, Journal of Aksaray University Faculty of Economics and Administrative Sciences, 1(2): 111-126. 
Ünlü, Y., Hamedoğlu, M.A. ve Yaman, E. (2015). Öğretmenlerin Örgütsel Adalet Algıları ve Örgütsel Sessizlik Düzeyleri Arasındaki İlişki, Sakarya University Journal of Education, 5(2): 140157.

Vakola, M. and Bouradas, D. (2005). Antecedents and Consequences of Organizational Silence: An Empirical Investigation, Employee Relations, 27(4-5): 441-458.

Van Dyne, L., Ang, S. and Botero, I.C. (2003). Conceptualizng Employee Slince and Emplyoee Voice as Multidimensional Constructs, Journal of Managment Studies, 40(6): 1359-1392.

Wu, L., Yim, F.H., Kwan, H.K. and Zhang, X. (2012). Coping with Workplace Ostracism: The Roles of Ingratiation and Political Skill in Employee Psychological Distress, Journal of Management Studies, 49(1): 178-199.

Wu, L.Z., Wei, L.Q. and Hui, C. (2011) Dispositional Antecedents and Consequences of Workplace Ostracism: An Empirical Examination, Frontiers of Business Research in China, 5(1): 2344.

Yan, Y., Zhou, E., Long, L. and Ji, Y. (2014). The Influence of Workplace Ostracism on Counterproductive Work Behavior: The Mediating Effect of State Self Control, Social Behavior and Personality, 42(6): 881-890.

Zhao, H., Peng, Z. and Sheard, G. (2013). Workplace Ostracism and Hospitality Employees' Counterproductive Work Behaviors: The Joint Moderating Effects of Proactive Personality and Political Skill, International Journal of Hospitality Management, 33: 219-227.

Zhao, H. and Xia, Q. (2017). An Examination of the Curvilinear Relationship Between Workplace Ostracism and Knowledge Hoarding, Management Decision, 55(2): 331-346. 